\title{
The Henry Chapman Site (41SM56)
}

\section{Mark Walters}

Heritage Research Center, Stephen F. Austin State University

Follow this and additional works at: https://scholarworks.sfasu.edu/ita

Part of the American Material Culture Commons, Archaeological Anthropology Commons, Environmental Studies Commons, Other American Studies Commons, Other Arts and Humanities Commons, Other History of Art, Architecture, and Archaeology Commons, and the United States History Commons

Tell us how this article helped you.

This Article is brought to you for free and open access by the Center for Regional Heritage Research at SFA ScholarWorks. It has been accepted for inclusion in Index of Texas Archaeology: Open Access Gray Literature from the Lone Star State by an authorized editor of SFA ScholarWorks. For more information, please contact cdsscholarworks@sfasu.edu. 


\section{The Henry Chapman Site (41SM56) \\ Creative Commons License \\ (c) $(1)(9)$}

This work is licensed under a Creative Commons Attribution-NonCommercial 4.0 International License 


\title{
The Henry Chapman Site (41SM56)
}

\author{
Mark Walters
}

\section{INTRODUCTION}

In the mid-1950s, Sam Whiteside conducted excavations at the Henry Chapman site, his site P-5 (41SM56), on Prairie Creek in eastern Smith County, Texas, some 18 miles east of Tyler, Texas. Mr. Whiteside was an amateur archaeologist who discovered and explored numerous sites up and down Prairie Creek as well as other important sites in Smith and adjoining counties (Walters 2005). The Chapman site was one of the first sites to be investigated by Mr. Whiteside, and the major part of the work took place there in 1957 and 1958.

In August 1957, the site was visited by Edward B. Jelks and Leroy Johnson, who viewed the excavations and examined artifacts collected from there. Mr. Jelks, in notes on record at the Texas Archeological Research Laboratory (TARL) at The University of Texas in Austin, Texas, on August 21, 1958, indicated after observing the artifacts from the Henry Chapman site that the ceramics indicated an Alto focus occupation. He recognized Hickory Engraved and Holly Fine Engraved wares as well as Dunkin Incised and possible Pennington Punctated-Incised sherds. He mentioned that no Crockett Curvilinear Incised or Weches Fingernail Impressed sherds were present (two common types present at the Alto focus type site, the George C. Davis site [41CE19]). E. Mott Davis also visited the site in late 1957, and in February 1959, Davis, Lathel F. Duffield, and William A. Davis collected skeletal material from the site. In a June 15, 1958, newsletter from the East Texas Archeological Society (ETAS), Mr. Whiteside described excavations at the Henry Chapman site that had revealed refuse pits, post holes, and an abundance of pottery sherds indicative of an Alto focus occupation.

In the summer of $1983, \mathrm{Mr}$. Whiteside visited the University of Texas Field School at the George C. Davis site, where he loaned some of his notes and collections from the Chapman site for recording purposes (these are on file at TARL).
After Mr. Whiteside's death, his family graciously allowed me access to his notes and artifacts. Not all of the artifacts have survived, having been stored in paper bags and subjected to several moves, but thanks to Mr. Whiteside's writing lot numbers on artifacts and listing them in a journal, a majority of them have survived, and thus are suitable for study. Although 50 years have passed since Mr. Whiteside's work at the Henry Chapman site, it is my intent to now make that work public.

\section{SETTING}

There are several Prairie Creeks in Smith County. This particular Prairie Creek has its headwaters in central Smith County some 10 miles east of Tyler. Prairie Creek then flows past the Chapman site about 10 miles in an easterly direction, joining the Sabine River near present day Gladewater, Texas. At the location of the Chapman site, the Prairie Creek floodplain is approximately $1 / 4-$ mile wide. The present day Prairie Creek channel is located on the opposite side of the floodplain from the site, but channel scars and meander are evidence that it has migrated back and forth across the floodplain in the past.

The Chapman site is located on a low sandy terrace some $8 \mathrm{ft}$. above the Prairie Creek floodplain. The terrace is approximately $100 \mathrm{x} 160 \mathrm{ft}$. in size, covering some $16,000 \mathrm{ft}^{2}$, or 0.4 acres. A spring branch forms the northern boundary of the site; the west side ends at a steep hillside; and the east and south boundaries are the Prairie Creek floodplain.

The landowner reported that the site was under cultivation for a two year period around 1940. After that it was allowed to return to native woodlands, and it was harvested for timber shortly before $\mathrm{Mr}$. Whiteside began excavations in 1957. For those unfamiliar with East Texas, nature here abhors empty spaces, rushing in at its first opportunity to cover the bare spots with all matter of vegetation. 
Only after successive generations of plant growth have evolved do the woods reach enough height to crowd out some of the brush and make the woods fairly open again. This mass of vegetation caused Mr. Whiteside to write in his notes at one point in bold letters "excavation very difficult."

\section{EXCAVATIONS}

Mr. Whiteside discovered the Chapman site in the winter of 1957 and obtained landowner permission to conduct excavations there. He noted that there was a lack of surface visibility due to the previously mentioned mass of vegetation and he also noted that there were few artifacts present in the first $0.5 \mathrm{ft}$. of excavations. It is not known whether this sterile layer was the result of soils being deposited on the site sometime after the prehistoric occupation ended, or if it is the product of the action of earthworms bringing sterile soil to the surface over a number of years.

After establishing a grid system over the site in $5 \times 5 \mathrm{ft}$. squares, Mr. Whiteside excavated a number of trenches across the site, expanding them into a series of contiguous $5 \times 5 \mathrm{ft}$. excavation blocks when cultural materials were encountered. Mr. Whiteside used feet and inches for measurements, that being the accepted practice at the time. Shovels, trowels, and a screen (probably with a $1 / 2$-inch mesh) were used in the excavations. At times, when working alone, $\mathrm{Mr}$. Whiteside stated in his notes that he did not screen all of the soil but relied on shovel-skimming, taking thin slices with the shovel or trowel to recover artifacts and expose features. Artifacts were collected in 6 inch $(0.5 \mathrm{ft}$.) intervals within each $5 \mathrm{x} 5 \mathrm{ft}$. excavation square. After washing, the recovered artifacts were given an individual catalog number (or lot number as used in the report) corresponding to their depth below the surface and North and East grid coordinates. A plan view was made depicting the excavation areas and the locations of identified features (most of the time). Profiles were made illustrating soil strata and vertical views of features.

Members of the ETAS, headquartered in Tyler, Texas, aided in the excavations. Those helping included Earl Ginn, Douglas Procter, Darrel Sanders, and E.W. Hayner. At times, Mr. Whiteside employed some of his farm laborers, including Ben Tolbert and Roscoe Ford, in excavations at the Chapman site. Mr. Whiteside's teenage son Jim was a big asset in the excavations and mapping.
Based on his notes, Mr. Whiteside excavated in the course of several years some $1800+\mathrm{ft}^{2}$ at the Henry Chapman site (Figure 1). In his notes, he indicated that excavations revealed three roughly circular 20-30 ft. diameter areas (I, II, and III) marked by increased artifact concentrations and darker carbonstained soils (Figure 1). He surmised that these areas represented circular house locations. Area I had the deepest midden deposits along with a large trash pit (Feature 2). Area II was marked by increased artifact densities; an arc of possible post holes (Feature 11); and several pit features. Soils were thinner in Area II and post holes were detected only when they extended into the clay subsoil. Area III was suggested to represent the location of a burned structure because of the presence of a fired mud dauber nest with grass and reed impressions on one side. Such nests are often constructed in protected locations such as inside structures (Walters 2008:66). There were also pieces of daub with grass/cane impressions and portions of a "green" unfired vessel that had been distorted by intense heat (Figure 2). There were no features identified in Area III, however.

Mr. Whiteside described a typical soil profile at the Chapman site as:

Zone 1, a dark brown (10YR3/3) to very dark brown $(10 \mathrm{YR} 2 / 2)$ organically enriched loamy fine sand that varies from 1 $\mathrm{ft}$. to $1.5 \mathrm{ft}$. bs. in depth. Area I is described as having the thickest Zone 1 deposits. Most of the prehistoric artifacts were recovered from this zone. At places, this zone is capped by $0.5 \mathrm{ft}$. of a sterile overburden attributed to slope-wash;

Zone 2, this is a yellowish-brown (10YR5/4) loamy fine sand that varies from $0.75-2 \mathrm{ft}$. in depth. Few artifacts were recovered from this zone; and,

Zone 3, a sticky, yellowish-red (5YR5/6) sterile sandy clay that varies in depth across the site. In Area II, the Zone 3 soils were closest to the surface, making features in this area more distinct because of the distinct soil color changes between Zones $1 / 2$ and the sandy clay.

\section{FEATURES}

Mr. Whiteside made note of several features discovered during excavations at the Chapman site, 


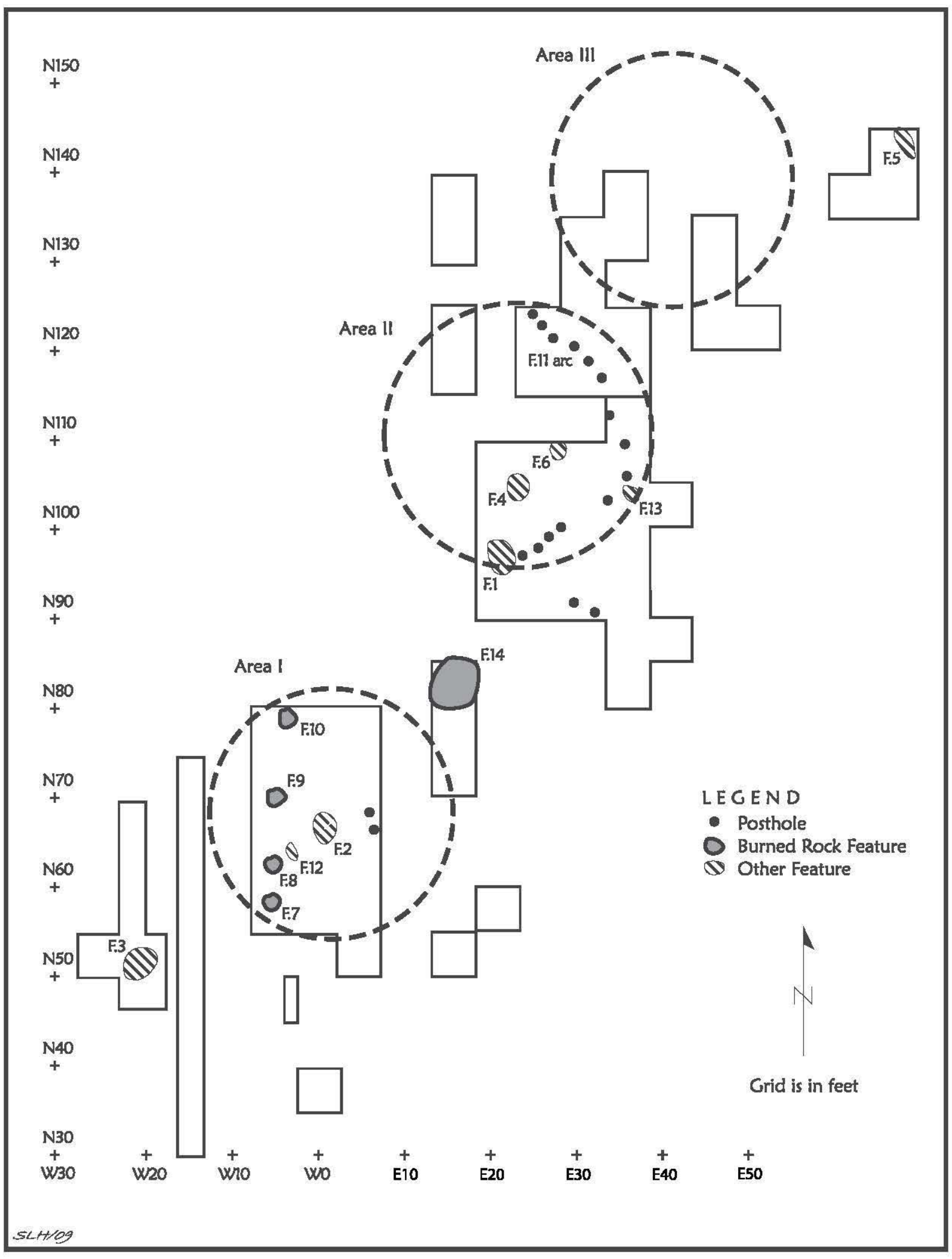

Figure 1. Plan of excavations at the Henry Chapman site (41SM56). 


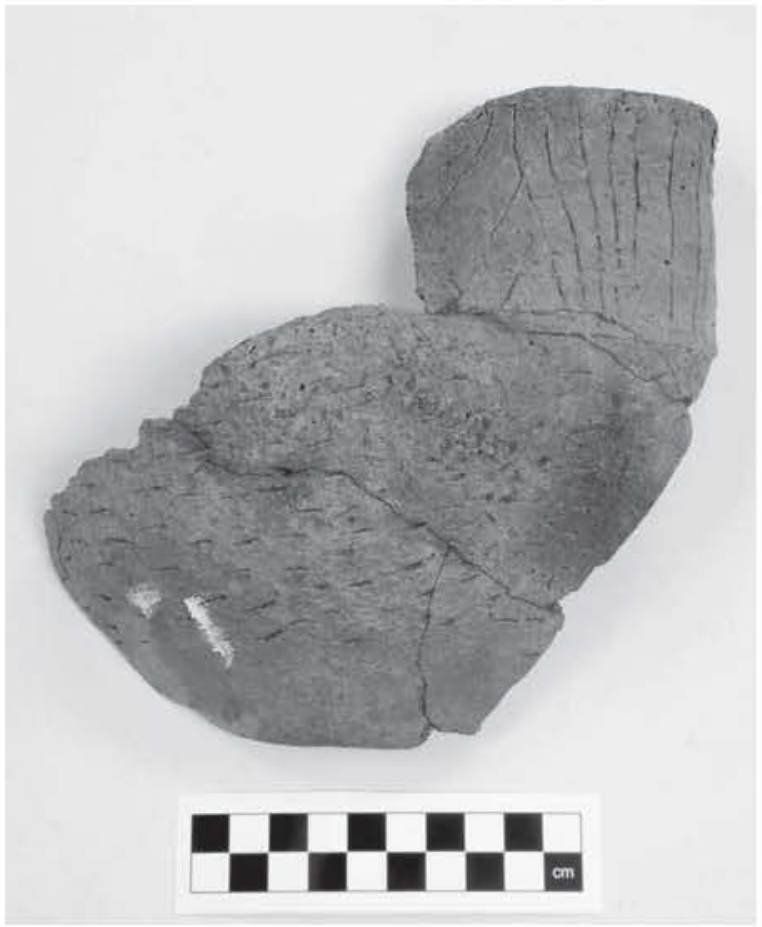

Figure 2. "Green" unfired vessel from Area III.

some in greater detail than others. Most of these features, excluding the two burials, were associated with the three areas (I-III) that Mr. Whiteside identified as possible house locations with associated pits and hearths (see Figure 1). Large pits are common on early Caddo sites and probably represent food storage facilities reused as trash receptacles after they were emptied of their intended contents. Hearths occur inside structures or in outdoor activity areas. One set of features in Area II was a partial post hole pattern from a Caddo house. Of the two burial features, one was a partial cremation that was associated with the Caddo occupation; the cultural affiliation of the other burial has not been determined.

\section{Feature 1 (N105-110 E20-25)}

This is a pit feature that is $2 \times 2.5 \mathrm{ft}$. in diameter and $2.5 \mathrm{ft}$. deep containing 56 sherds; four partially reconstructed vessels (see whole vessels); animal bone, including a deer skull fragment with attached antler; deer teeth and vertebra; mussel shell; flakes; and a smoothing stone. The sherds included two that are engraved, one an engraved rim with opposing diagonal lines; 30 incised sherds, including two rims; and 24 plain sherds, including two plain rims.

\section{Feature 2 (N75-80 E0-5, 2 ft. bottom depth)}

The feature is a dark charcoal-rich stain (Figure $3 \mathrm{~b}$ ) that is approximately $3 \mathrm{ft}$. in diameter and extended to $3 \mathrm{ft}$. bs. Artifacts included in the fill are flakes, sherds (three incised, one engraved, and three plain body), and animal bones. Charred animal bone collected from $0.5-1.0 \mathrm{ft}$. bs in the feature fill was submitted to The University of Texas at Austin on February 28,1958 , for a radiocarbon date, but were never actually submitted for radiocarbon dating. Records at TARL show the specimens were discarded on August 21, 1969, without being analyzed.

\section{Feature 3 (N59.5-63.5 W16.5-20.0, 2.5 ft. bottom depth)}

On November 25, 1957, in a trench (N60-70 W 15-20) excavated by Ben Tolbert and Roscoe Ford, a charcoal stain was noted at $2.5 \mathrm{ft}$. depth. Excavations exposed a $3.5 \mathrm{ft}$. diameter pit that extended to $3 \mathrm{ft}$. bs with charred logs and human bone underneath the charred logs (Figure 4). A skull was on the north side of the pit, on its left side facing to the east. The lower $0.67 \mathrm{ft}$. of the burial pit was very black from charcoal staining. The lower part of the burial pit also had clay mottles that were the result of the pit having been dug into the clay subsoil. A clear pit outline could not be determined above $2.5 \mathrm{ft}$. bs in the dark brown cultural zone, but below that depth a circular pit approximately $3.5 \mathrm{ft}$. in diameter was observed. Artifacts in the pit fill indicated that the pit had been dug into and through an existing Caddo occupational deposit.

According to Mr. Whiteside's journal, he turned over skeletal material, including a cranium, from the Henry Chapman site on February 24, 1959, to E. Mott Davis. E. Mott Davis's personal journal notes on Tuesday, February 24, 1959, that "we (E. M. Davis, L. F. Duffield, and W. A. Davis) drove to Sam Whiteside's at Tyler... Sam gave us... skeletal material from his P-5 site." There were other scattered human bones in the pit, but it is not clear from the notes if all of the bone was charred. Records from TARL indicate that there are two human remain entries from the Chapman site but it is not conclusive at this time if these remains are actually from the Chapman site.

A $0.5 \mathrm{ft}$. diameter charred $\log$ lay east-west across the head/neck area of the grave, and two samples were collected for radiocarbon dating, although the exact whereabouts of these samples are not known. A second log, not as well preserved, lay in a north-south direction on the west side of the pit. A portion of one of the charred logs survived in the 


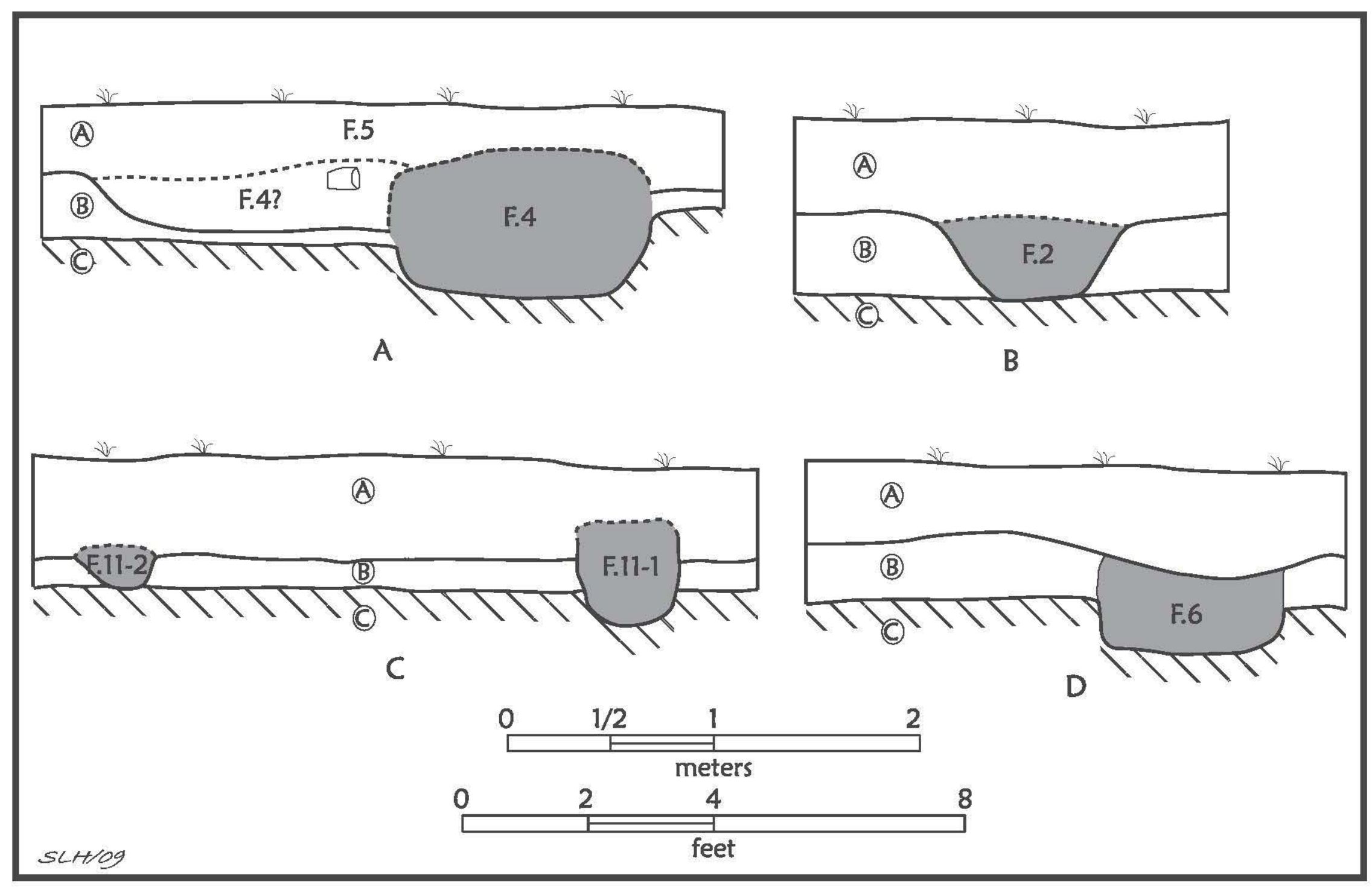

Figure 3. Profiles of features and archaeological deposits: a, Feature 4; b, Feature 2; c, Feature 11-1 and 11-2; d, Feature 6. 


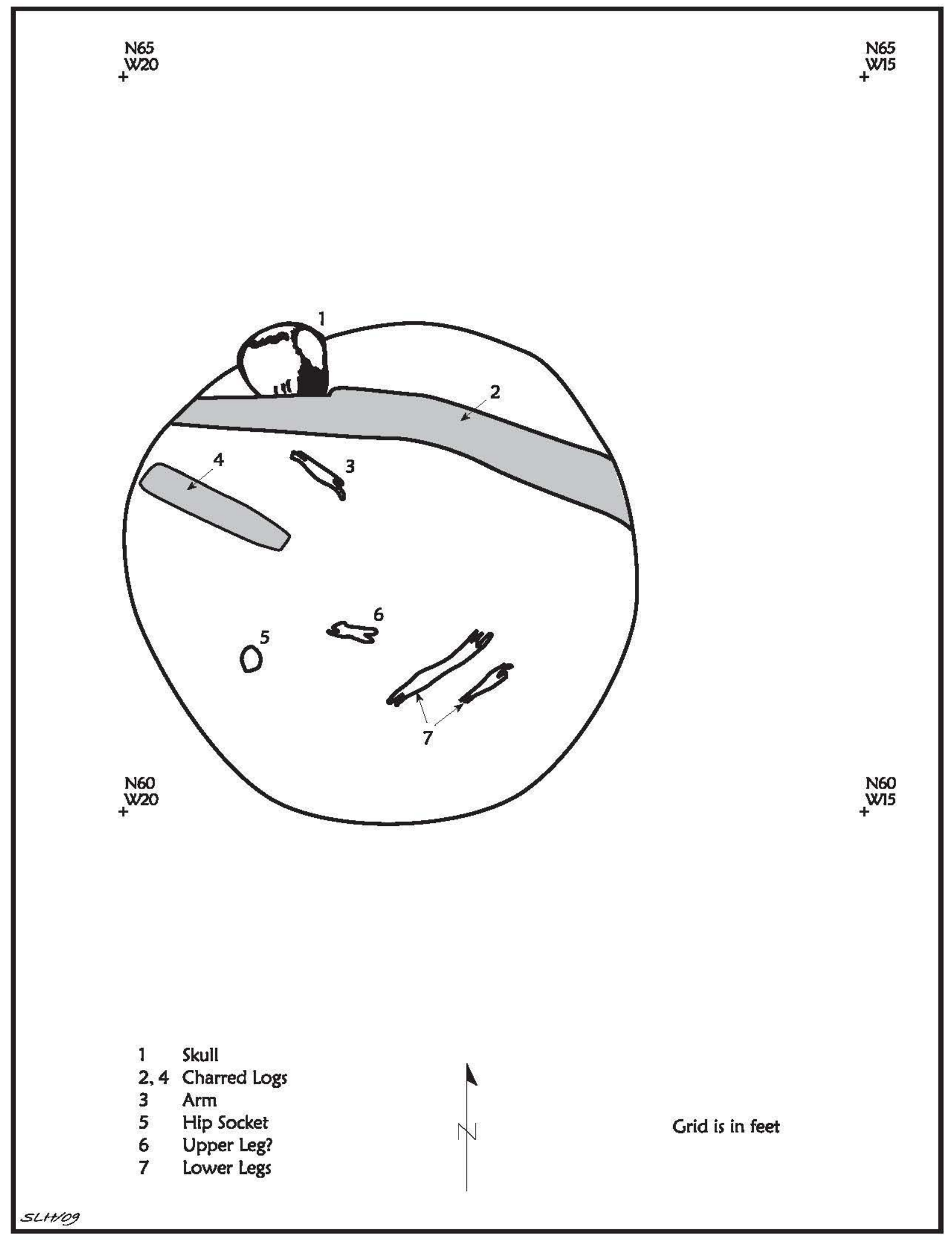

Figure 4. Plan map of Feature 3. 


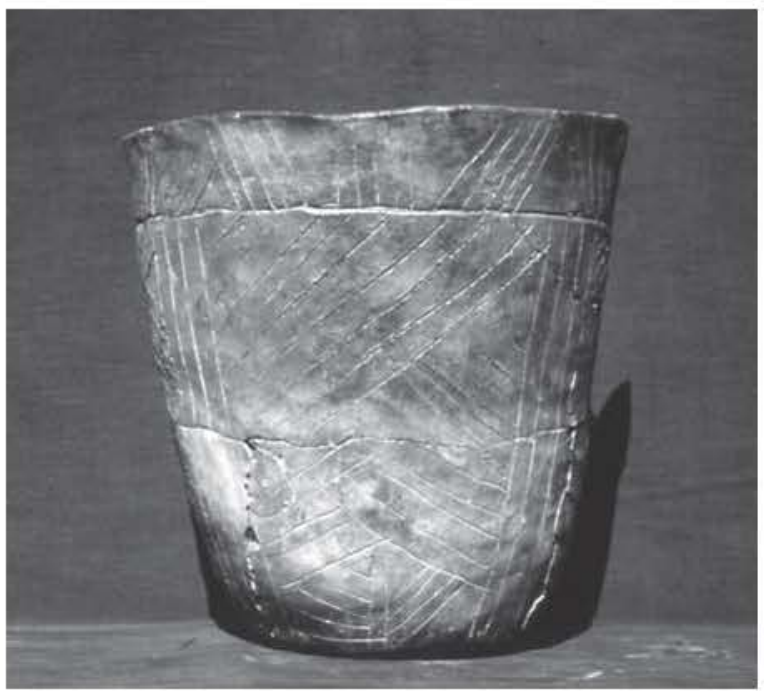

Figure 5. Dunkin Incised jar from Feature 4.

Whiteside collection and was submitted by the author for radiocarbon dating, yielding a 2 sigma calibrated age range of $\mathrm{AD} 1280-1440$. There were no obvious grave goods associated with the burial. Mr. Whiteside speculated in his notes that after the body had been placed in the pit, a fire was built over the body, partially consuming it and charring the bones. The pit was then refilled with soil that was used to extinguish the fire before the logs were completely oxidized.

Caddo ceramics in the burial fill of Feature 3 include four incised body sherds; one incisedpunctated rim with diagonal incised lines separating triangular zones of tool punctates; one rim with broad excised horizontal bands and red pigment; and three plain body sherds. There were also two ferruginous sandstone slabs in the burial fill. They were unmodified, and measured $5 \times 4 \mathrm{~cm}$ in length and width, and were $1.0 \mathrm{~cm}$ thick.

\section{Feature 4 (N110-115 E 25-30, Bottom depth: 3 ft. bs)}

This is a circular-shaped pit, although the exact dimensions are not clear. Based on the profile, it appears to have been ca. $9 \mathrm{ft}$. in diameter, with a $4 \mathrm{ft}$. diameter portion that extended to $3 \mathrm{ft}$. bs, well into the clay subsoil (see Figure 3a). The deeper portions of the pit feature were first identified at $1 \mathrm{ft}$. bs, and found in it was one rim sherd with diagonal incised lines, an incised body sherd, and three plain body sherds. The shallow portion of the pit contained most of a Dunkin Incised jar (Figure 5), with a bottom depth of $1.5 \mathrm{ft}$. bs.

\section{Feature 5 (N150-155 E65-70, Bottom depth is $2 \mathrm{ft}$. bs)}

This is a possible burial feature in Area III (see Figure 1). In Mr. Whiteside's journal, lot numbers 1056-1082 are listed as B2 with artifacts collected from $0-2 \mathrm{ft}$. However, there is no description of these artifacts. At TARL, there is a long bone and adultsized skull fragment (about $2 \times 3$ inches in size), neither of which are burned. A tag in the box reads "P-5 bone, Burial 2, Whiteside cat. \#1147." This is in agreement with $\mathrm{Mr}$. Whiteside's journal entry for Lot 1147: Bone B2.

\section{Feature 6 (N118 E30, Bottom depth, $2.83 \mathrm{ft} . \mathrm{bs}$ )}

Feature 6 is a ca $2.0 \mathrm{ft}$. diameter circular pit inside an arc of possible post holes. The pit extended into the clay subsoil (see Figure $3 d$ ). The only artifact listed as being found in Feature 6 is one plain sherd.

\section{Features 7-10}

These are burned rock features exposed at 1.67 $\mathrm{ft}$. bs, with the following Area I proveniences at the site: Feature 7, N58 W2; Feature 8, N60 W4; Feature 9, N72.5 W5; and Feature 10, N79 W5.6 (see Figure 1).

\section{Feature 11-Area II (N105-135 E10-40)}

Feature 11 is an arc of 14 post holes of what appears to be a circular house structure roughly 20 $\mathrm{ft}$. in diameter (see Figure 1). The distance to the clay sub-soil was shallower ( $2 \mathrm{ft}$. bs) in this area and $\mathrm{Mr}$. Whiteside was able to distinguish the post hole stains as they appeared in the clay subsoil. He indicated the depths of the posts were irregular, the pattern being a large post placed at $4 \mathrm{ft}$. intervals set to a total depth of $2.5-3 \mathrm{ft}$. bs in the ground, with smaller posts placed between that were set at depths of $2 \mathrm{ft}$. (see Figure 3c).

\section{Feature 12}

Feature 12 is a hearth (N63.5 W1) inside Area I, a possible house location (see Figure 1). The hearth was marked by a $2 \mathrm{ft}$. diameter ash deposit at $1.5 \mathrm{ft}$. bs. 


\section{Feature 13}

Feature 13 is a hearth with ash deposits in Area II (N101 E36). This feature was associated with a pattern of post holes from a circular structure, but it was situated outside of the post hole arc, suggesting it may have been an outdoor hearth (see Figure 1). The feature was exposed at $0.67 \mathrm{ft}$. bs.

\section{Feature 14}

Feature 14 is a concentration of rocks (N80-85 E15-20) uncovered at $1.83 \mathrm{ft}$. bs by Area I (see Figure 1). No other information is available about the character of the rock feature.

\section{Radiocarbon date}

There is one radiocarbon date from the Henry Chapman site on charred wood from Feature 3. The conventional age is $580 \pm 60$ B.P. (Beta-129978). The calibrated intercept is AD 1400 (cal BP 550).
At two sigma, there is a $95 \%$ chance that the calibrated age of the wood charcoal falls between $\mathrm{AD}$ $1280-1440$.

\section{ARTIFACTS FROM THE HENRY CHAPMAN SITE}

A total of 543 artifacts remain from the $1950 \mathrm{~s}$ excavations by Sam Whiteside at the Henry Chapman site (Table 1). More than $84 \%$ of the recovered artifacts are plain and decorated ceramic sherds and vessels/partial vessels, with small amounts of lithic tools and debris $(8.4 \%)$, animal bone $(6 \%)$, and mud dauber nests and pieces of daub $(0.9 \%)$. Notable by their absence are ceramic pipes, which occur in varying numbers on most East Texas Caddo sites.

\section{Ceramic Sherds}

There are 453 sherds included in the Henry Chapman collection, of which 286 are decorated

Table 1. Artifacts from the Henry Chapman Site.

\begin{tabular}{llc}
\hline Artifact Class & Type & No. of Specimens \\
\hline Ceramics & Decorated sherds & 286 \\
& Plain rims & 25 \\
& Plain body sherds & 132 \\
& Base sherds & 10 \\
& Whole/partial vessels & 7 \\
& Sub-total & 460 \\
Lithics & Flakes & 19 \\
& Points/tools & 14 \\
& Celts & 5 \\
& Cores/tested cobbles & 5 \\
& Abraders & 3 \\
Fauna & Sub-total & 46 \\
Miscellaneous & Animal bone & $32^{*}$ \\
\hline Total & Fired mud dauber nests & 2 \\
\hline
\end{tabular}

* An unknown number of charred animal (Lot \# 516) bone was submitted for radiocarbon dating by The University of Texas in 1958 , but they were never analyzed. 
Table 2. Decorated Sherds.

\begin{tabular}{lcc}
\hline Decoration & No. & Percentage \\
\hline Punctated & 96 & 33.6 \\
Engraved & 84 & 29.4 \\
Incised & 74 & 25.9 \\
Punctated-incised & 32 & 11.2 \\
\hline Totals & 286 & 100.1 \\
\hline
\end{tabular}

(see Table 1). The plain to decorated sherd ratio is only $0.6: 1$.

The decorated sherds (Table 2) from the site have four different decorative methods. The utility wares include sherds with punctated, incised, and punctated-incised designs; these sherds comprise $70.5 \%$ of the decorated sherds. Utility ware types that are found on East Texas Early Caddo sites (ca. A.D. 900-1200), such as Dunkin Incised and Crockett Curvilinear Incised, are present at the Chapman site, although other early utility ware types such as Weches Fingernail Impressed and Pennington Punctated-Incised are apparently absent. The remainder of the decorated sherds are from engraved fine ware vessels. The absence of brushed wares at the Chapman site, found in increasing percentages on later (post-A.D. 1200) Caddo sites in the area (see Walters 2008; Walters and Haskins 1998), would suggest that the Chapman site was primarily occupied earlier than ca. A.D. 1200 in the Caddo sequence in this part of East Texas.

On average, the utility wares at the Henry Chapman site are thicker (Table 3 ) than the fine wares, and about the same thickness as the plain wares. The utility wares usually have a coarser paste than the fine wares, and are mostly large jars with smoothed interior surfaces.

As our knowledge of prehistoric Caddo potters and the pottery they made increases, it is evident that they chose from a number of different techniques to achieve a desired effect when making and firing their wares. Like all learned activity, this process had temporal and spatial differences. Were there differences in, for instance, how utility and fine wares were fired at the Chapman site? At the Chapman site, $87 \%$ of the fine ware sherds came from vessels that were fired in a reduced atmosphere, and $13 \%$ are sherds from vessels fired in an oxidized atmosphere (Table 4). Of the plain wares, $81 \%$ of the sherds were
Table 3. Sherd Thickness.

\begin{tabular}{lc}
\hline All sherds & $\begin{array}{c}\text { mean thickness } \\
(\mathrm{mm})\end{array}$ \\
\hline engraved rim & 6.2 \\
engraved body & 5.4 \\
punctated rim & 7.4 \\
punctated body & 8.7 \\
incised rim & 7.4 \\
incised body & 7.8 \\
punctated-incised rim & 8.0 \\
punctated-incised body & 7.6 \\
plain rims & 7.6 \\
plain body & 9.0 \\
bases & 11.1 \\
\hline
\end{tabular}

Average thickness for

all sherds (excluding 10 bases) $\quad 7.5 \mathrm{~mm}$

fired in a reduced atmosphere and only $19 \%$ were from vessels fired in an oxidizing atmosphere. The utility wares were fired in much the same manner, as $78 \%$ of the utility ware sherds are from vessels that were fired in a reduced atmosphere and $22 \%$ of the sherds were from vessels fired in an oxidizing atmosphere. Of the 10 bases, eight $(80 \%)$ were fired in a reduced atmosphere and two (20\%) were fired in an oxidizing atmosphere. At the Chapman site, then, the Caddo potters employed similar firing techniques for all pottery wares that emphasized the firing of vessels in a low oxygen environment, probably smothered in a bed of coals.

The tempers used by the Caddo potters at the Henry Chapman site were determined by visual observation, or aided by a $10 \mathrm{X}$ hand lens, of fresh breaks along sherd cross-sections. Grog is the major tempering agent, occurring in almost $99 \%$ of the sherds (Table 5), primarily as the sole temper, or in combination with bone and/or hematite. In some of the thick utility wares, a coarse grog is so prevalent that the sherds have a coarse and crumbly texture. Bone in varying amounts is present in over $35 \%$ of the sherds, while crushed ferruginous sandstone, or hematite as it is commonly referred to in the literature, occur in $12.4 \%$ of the sherds but never in any significant amounts.

The fine wares $(n=84)$ had $49 \%$ grog temper alone and $41 \%$ had bone and grog or bone alone. 
Table 4. Firing conditions.

\begin{tabular}{lcc}
\hline Decoration & Reduced & Oxidized \\
\hline Punctated & 71 & 25 \\
Engraved & 73 & 11 \\
Incised & 60 & 14 \\
Punctated-incised & 27 & 5 \\
Plain & 127 & 30 \\
Bases & 8 & 2 \\
\hline Totals & 366 & 87 \\
Percentage & 81.0 & 19.0 \\
\hline
\end{tabular}

Plain wares $(\mathrm{n}=157)$ had $57 \%$ grog as the sole temper, compared to utility wares $(\mathrm{n}=202)$ that had $55 \%$ grog temper. Plain and utility ware pottery sherds had almost equal amounts of bone temper, 36\% and $38 \%$ respectively, in combination with grog and hematite or as the sole temper (see Table 5).

\section{Decorated sherds}

\section{Engraved wares ( $n=84)$}

The engraved sherds comprise almost $30 \%$ of the decorated sherds from the Chapman site; 55 are body sherds and 29 are rim sherds. The average sherd thickness for the engraved wares is $5.8 \mathrm{~mm}$. The rim sherds are slightly thicker $(6.2 \mathrm{~mm})$ than the body sherds $(5.4 \mathrm{~mm}$ ) (see Table 3 ). This is probably a sampling error as most of the rims showed that wall thickness increases with wall vessel height, as is common in coil-constructed ceramics. With respect to surface treatment of the fine wares, $70 \%$ have interior and exterior smoothed surfaces, and $12 \%$ have a burnished surface; one sherd has an eroded surface.

There are 29 engraved rim sherds: 19 have Holly Fine Engraved design elements (Figure 6a-d) consisting of fine engraved lines in sets; six also have excised areas (Figure 6c-d). Six of the Holly Fine Engraved rims are from carinated bowls; the mean orifice diameter of these vessels is $18.5 \mathrm{~cm}$. Nine of the rims have design elements similar to Hickory Fine Engraved; three are from bottles. Three of the Hickory Fine Engraved rims have parallel curved lines, one with red pigment (Figure 6h-i). Another from Feature 3 has broad ( $4.6 \mathrm{~mm}$ wide) horizontal excised lines with red pigment (Figure $6 \mathrm{~m})$. One engraved rim, thinned with a rounded lip, has a cross-hatched design (Figure 6e). Another rim, direct with a flattened lip that is slanted towards the inside of the vessel, has diagonal engraved lines (Figure 6g). Finally, one engraved rim has a diagonal ladder motif (Figure 6f)

Twenty-one ( $72 \%$ ) of the 29 engraved rims are direct with rounded lips. Seven $(24 \%)$ are direct with flat lips. One flat rim has a tear-dropped indentation on top of the lip. There is one everted rim form with a flat lip.

Of the 55 engraved body sherds, 17 are likely from Holly Fine Engraved vessels. These sherds have fine engraved lines in sets (some more finely executed than others), six have excised areas, and two have red pigment in the lines (see Figure 6n).

Table 5. Temper.

\begin{tabular}{lccccc}
\hline All sherds & Grog & $\begin{array}{c}\text { Bone/ } \\
\text { grog }\end{array}$ & $\begin{array}{c}\text { Bone } \\
\text { hematite }\end{array}$ & $\begin{array}{c}\text { Bone/grog/ } \\
\text { hematite }\end{array}$ & Grog/ \\
\hline Punctated & 50 & 36 & - & 5 & 5 \\
Engraved & 41 & 29 & 5 & - & 9 \\
Incised & 41 & 17 & - & 2 & 14 \\
Punctated-Incised & 19 & 9 & - & 3 & 2 \\
Plain body & 79 & 40 & - & 1 & 3 \\
Plain rims & 11 & 10 & - & - & - \\
Bases & 8 & 2 & - & 13 & 43 \\
\hline Totals & 249 & 143 & 5 & 2.9 & 9.5 \\
Percentage & 55.0 & 31.6 & 1.1 & & 3 \\
\hline
\end{tabular}




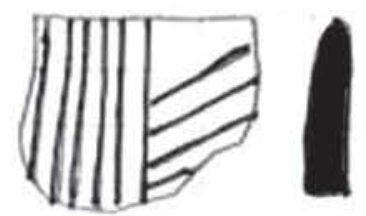

a
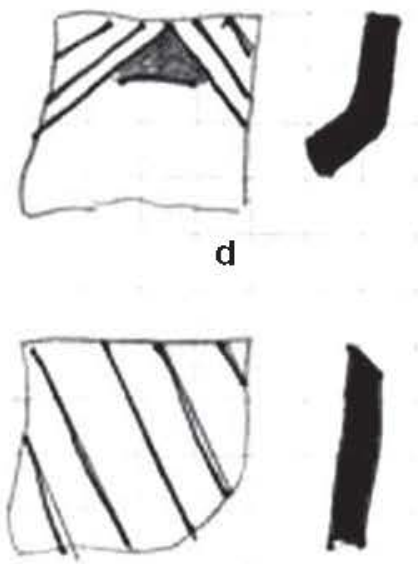

g
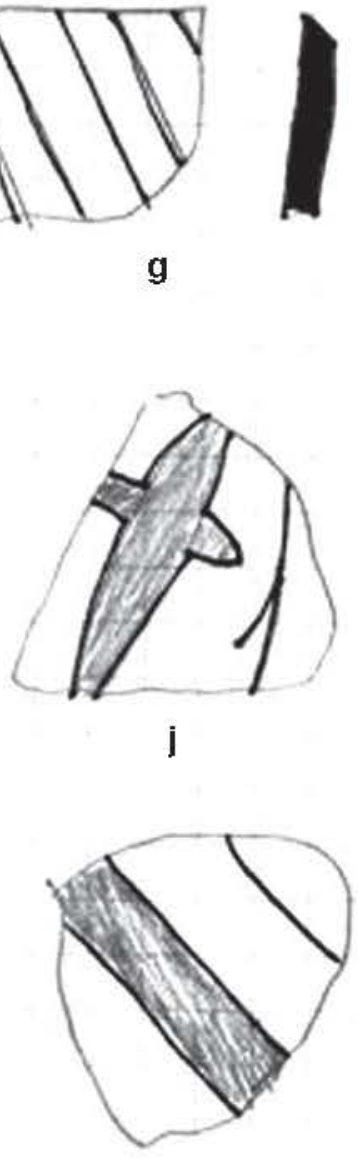

m

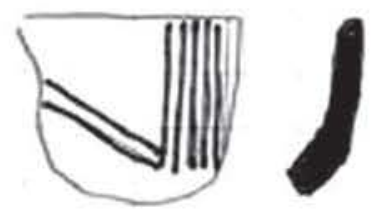

b

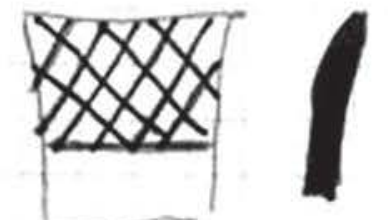

e

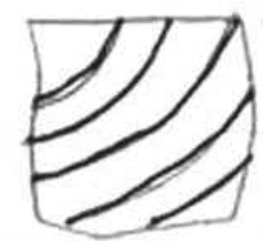

h
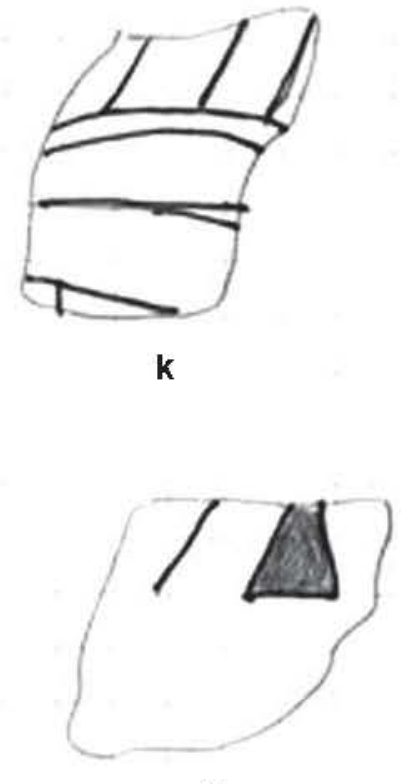

n

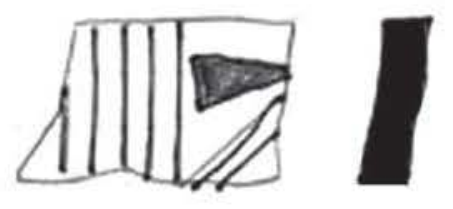

c

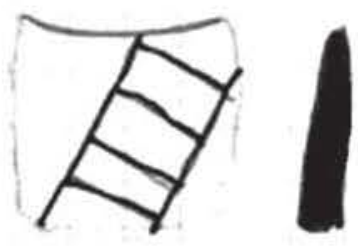

f

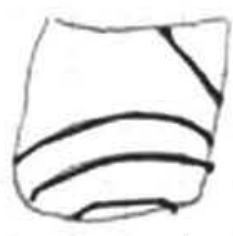

i
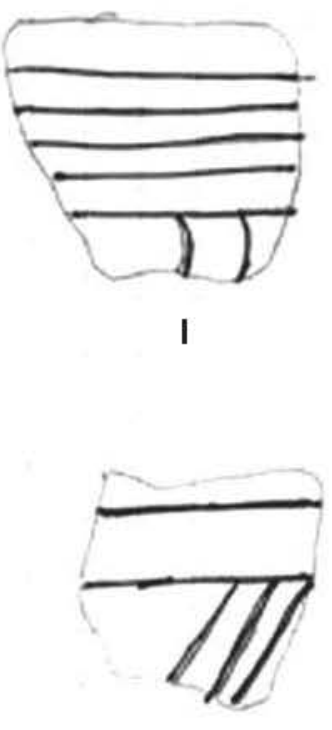

o

Figure 6. Selected engraved rim and body sherds: a-d, n, Holly Fine Engraved; e, cross-hatched zone; $f$, diagonal ladder engraved motif; g, diagonal engraved lines; $h$-i, $m$, Hickory Fine Engraved; j, excised cross-shaped element; $k-1$, parallel and curvilinear lines. 


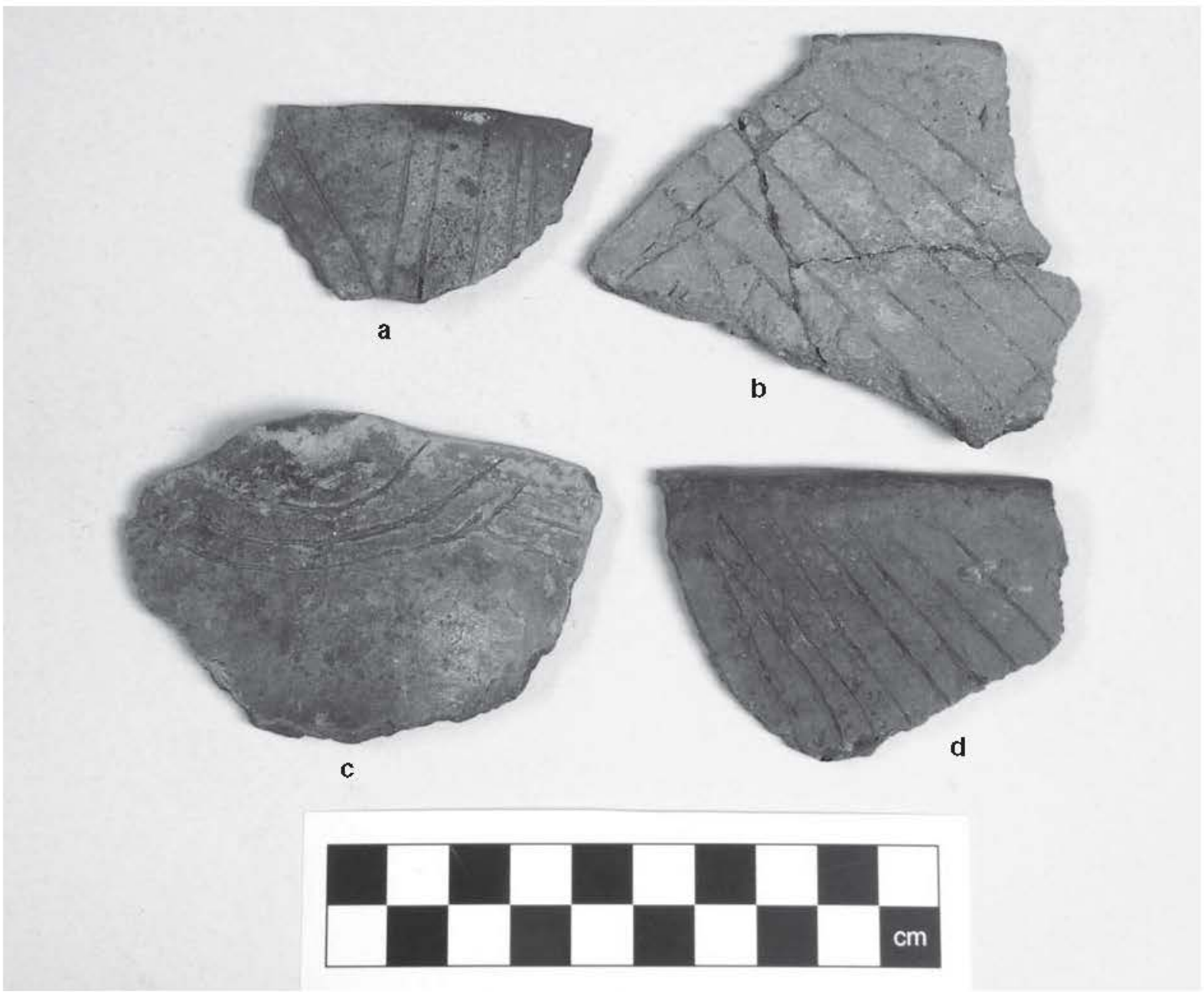

Figure 7. Incised rim sherds: a-b, d, multiple diagonal or diagonal opposed incised lines; $c$, horizontal incised and a lip tab.

Nine are from carinated bowls. Eight Hickory Fine Engraved sherds, six of which are from bottles, represent the other recognizable type in the fine wares. Other design elements are 13 sherds with multiple curvilinear lines and nine sherds with multiple straight engraved lines. There are three body sherds with single straight engraved lines and one with a single curvilinear line. Three sherds had opposing straight lines (see Figure 6o). One engraved body sherd has curvilinear lines with opposing engraved lines (see Figure 6k), and another has parallel engraved lines with opposing lines (see Figure 61). Finally, there is a body sherd with an excised "cross-shaped" element with red pigment (see Figure 6j). Differing from later Caddo ceramic styles in the region, the engraved fine wares from the Henry Chapman site seldom used an upper or lower line on the rim marking the limits of the motif.

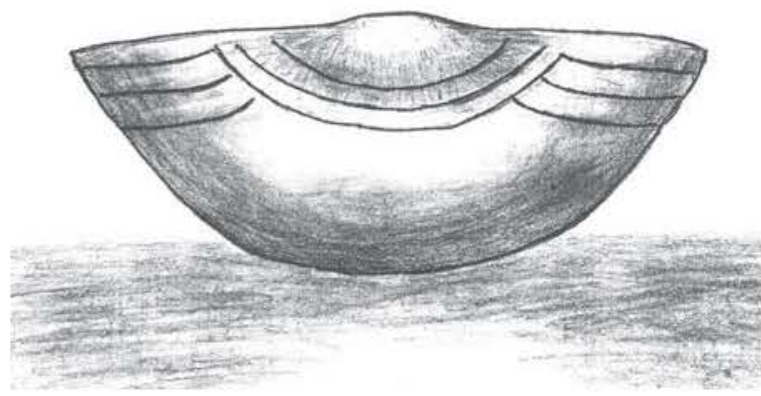

Figure 7e. Drawing of reconstructed horizontal incised and lip tab vessel.

\section{Incised rims ( $n=23$ )}

Twelve of the incised rim sherds have multiple, diagonal, straight incised lines (Figure 7a-b, d), while 
one sherd has a single diagonal line. One rim with diagonal lines, from N75-80 E0-5, 0.5-1.0 ft. bs, had been re-fired. Three other incised rims have horizontal lines; another has a single horizontal line under a rolled-out lip. These horizontal incised sherds are probably from Davis Incised vessels, a common type found in early Caddo ceramic assemblages.

One incised rim (N70-90 W0-5) from a bowl had a thickened rim tab with three horizontal lines that dipped underneath the tab (see Figure 7c, e). The sherd is grog-tempered and has been fired in a reduced atmosphere and cooled in the open air. The exterior and interior surfaces are burnished. The rim is direct and has a round lip; its orifice diameter is $20 \mathrm{~cm}$, and it is $6.4 \mathrm{~mm}$ thick.

Two incised rims have cross-hatched lines. Four other rims have either opposing straight lines $(n=2)$, opposing curved lines $(\mathrm{n}=1)$, or opposing diagonal incised lines $(\mathrm{n}=1)$.

Thirteen of the incised sherds $(57 \%)$ have direct rims, mainly with rounded lips. As previously mentioned, one of these direct rims has a lip tab (see Figure 7c); two have exterior folded lips and are smoothed. Ten have direct rims with flat lips. The average thickness of the incised rims is $7.4 \mathrm{~mm}$ (see Table 3), with a thickness range from 5.4-10.8 mm.

\section{Incised Body Sherds ( $n=50)$}

Thirty-four incised body sherds have parallel straight lines as decoration. Two of these are from vessels that had been refired (one from N105-110 E30-35, 0-0.5 ft. bs; the other from N70-90 E 0-5, no depth). On one of these sherds, a hollow reed was employed to make the incised lines.

Another of the incised body sherds, with a portion of the base attached, had vertical straight lines. Seven have opposing incised straight lines, one forming a chevron design. Seven incised body sherds have a single straight line. One sherd has a cross-hatched element on a thickened portion of the sherd. None of the incised sherds from the Chapman site had obvious overhanging lines, a characteristic attribute of Coles Creek Incised (Phillips 1970:7076), a Lower Mississippi Valley type that is occasionally found on early Caddo sites.

The incised body sherds have an average thickness of $7.84 \mathrm{~mm}$ (see Table 3). Forty-six sherds (92\%) have smoothed exterior and interior surfaces. Five sherds have exterior burnished surfaces below the incised decoration and interior smoothed surfaces.

\section{Punctated Rims ( $n=7)$}

Three of the punctated rims have random tool punctates (Figure 8a-b), three have randomly placed fingernail punctates, and one rim has horizontal rows of tool punctates. Five rims have direct rim profiles and flat lips. One rim has a direct profile and a round lip, while the other punctated rim is everted in profile with a round lip. Average thickness of the punctated rims is $7.4 \mathrm{~mm}$ (see Table 3 ).

\section{Punctated Body Sherds ( $n=89)$}

More than $85 \%$ of the punctated body sherds have random fingernail punctates (see Figure $8 \mathrm{c}-\mathrm{d}$ ) that appear to have covered the vessel body. Seven others have random tool punctates $(7.9 \%)$, five have rows of tool punctates $(6.3 \%)$, and one $(1.1 \%)$ has rows of fingernail punctates. Average thickness of the punctated vessel body sherds is $8.7 \mathrm{~mm}$, but with a range of $4.3-14.7 \mathrm{~mm}$.

\section{Punctated-incised Rims ( $n=16)$}

Eight of the punctated-incised rims from the Henry Chapman site have opposed diagonal lines that form triangular areas that are filled with tool punctates (Figure 9a-b, d). One of these also has a diagonal incised panel filled with tool punctates adjacent to one of the triangular punctated-filled areas (Figure 9a). Five rims have parallel diagonal lines arranged in opposite directions, forming triangles that are instead filled with fingernail punctates. Another punctated-incised rim has opposing straight lines on the rim and random fingernail punctates on the body section; this sherd had been exposed to extreme heat as evidenced by a crazed surface. One rim has vertical parallel lines separating a zone of random fingernail punctates. Finally, there is one rim with curvilinear parallel incised lines and zones of random tool punctates (Figure 9c). The decorative elements on this sherd resemble those documented for Crockett Curvilinear Incised ceramic vessels. This ceramic type is found in association with early Caddo fine ware types such as Holly and Hickory Fine Engraved (cf. Suhm and Jelks 1962).

Twelve punctated-incised rims are from jars. Seventy-five percent of the punctated-incised rims have direct rim profiles with round lips. Three are direct with flat lips and one punctated-incised rim has an everted rim profile with a round lip. The average thickness of the punctated-incised rims is 8.0 $\mathrm{mm}$ (see Table 3). 


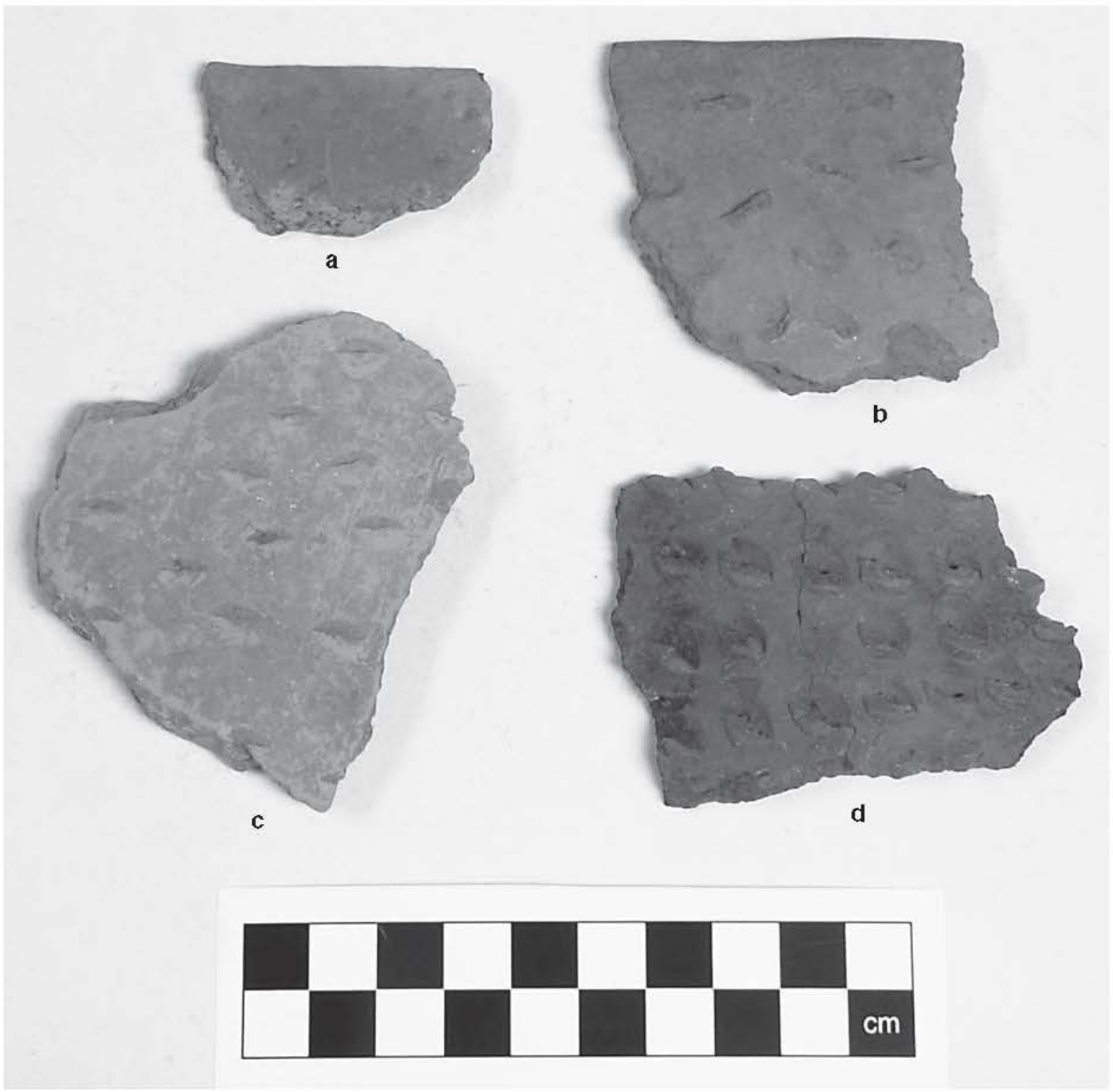

Figure 8. Selected punctated rim and body sherds from the Henry Chapman site: $a-b$, random tool punctates on the vessel rim; $\mathrm{c}-\mathrm{d}$, random fingernail punctates on the vessel body.

\section{Punctated-incised body ( $n=16)$}

Five punctated-incised body sherds have opposing parallel straight lines separating zones of random fingernail punctates. Two sherds have parallel straight lines separating zones of fingernail punctates; two sherds have straight lines separating zones of reed punctates; one sherd has diagonal parallel straight lines separating a zone of fingernail punctates; and six sherds have curvilinear lines, four separating zones with fingernail punctates, and two with tool punctates.
One punctated-incised body sherd with reed punctates (N135-140 E30-35, depth $1.0-1.5 \mathrm{ft}$. bs) can be differentiated from the majority of the sherds from the Chapman site. The sherd is heavily grog-tempered, is from a vessel fired in a reduced atmosphere, and is $5.5 \mathrm{~mm}$ thick. It is decorated with a broad well-defined straight incised line bordering a row of well executed reedlike punctates. The design is similar to Evansville Punctated, var. Rhinehart, a Lower Mississippi Valley ceramic type that dates to the Coles Creek period (Phillips 1970:80-81). 


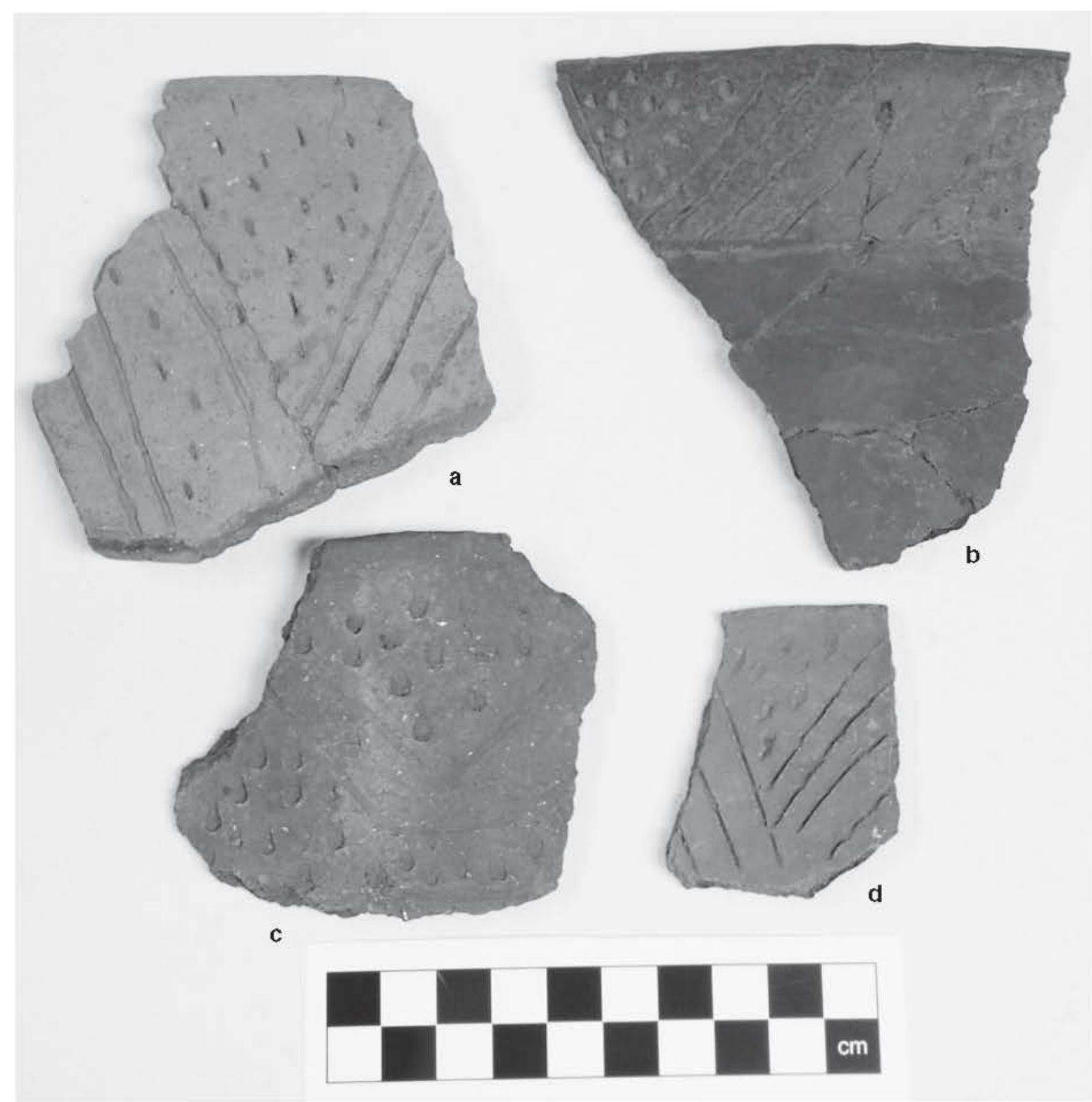

Figure 9. Punctated-Incised rims: a-b, d, triangular incised areas filled with tool punctates; $c$, curvilinear incised and random tool punctated zone.

\section{Plain Wares}

\section{Plain rims $(n=25)$}

The average thickness of the plain rims from the Henry Chapman site is $7.6 \mathrm{~mm}$ (see Table 3). Eight are direct rims with flat lips and 17 are direct rims with round lips; one of these is a bottle neck rim with an orifice diameter of $4 \mathrm{~cm}$. One of the plain rims is from a carinated bowl with an orifice diameter of $24 \mathrm{~cm}$. There is also a large plain jar rim from Feature 1.

\section{Plain body sherds ( $n=132$ )}

There are 132 plain body sherds from the Henry Chapman site. The average thickness of the body sherds is $9.0 \mathrm{~mm}$ (see Table 3 ). Almost $69 \%$ have smoothed interior and exterior surfaces, and $30.4 \%$ have burnished surfaces; one sherd has a burnished interior and smoothed exterior surface.

Ten plain sherds are from bottle necks. All had smoothed exterior surfaces and rough interior surfaces. The average thickness for these bottle sherds is $6.4 \mathrm{~mm}$. All of the bottle necks are cylindrical to slightly tapered toward the mouth. 


\section{Bases $(n=10)$}

All of the bases are flat, and thicker in the middle than along the edges. The average base sherd thickness is $11.1 \mathrm{~mm}$ (see Table 3 ), but with a range of 6.4-15.6 mm. Six of the bases have straight walls leading from the base, and two of these have very abrupt angles. The remaining four bases have body walls that slope at an angle away from the base, such that the base is smaller in diameter than the body of the vessel.

\section{Whole/partial vessels}

Seven whole or partial vessels were found in the excavations at the Henry Chapman site. Four of these vessels are from Feature 1, one is from Feature 4 , and the other two were not uncovered from feature contexts.

Vessel 1, N75 W4, $1 \mathrm{ft}$. bs

Form: It is a jar that is approximately $25 \%$ complete (see Figure 2). The vessel was warped, possibly from being damaged before final firing and still in a leather stage, then subjected to extreme heat such as would occur in a house fire.

Temper: Grog.

Rim-lip profile: Direct rim with a rounded lip.

Firing: Oxidized.

Color: grayish-brown on both interior and exterior surfaces.

Thickness: rim, $7.0 \mathrm{~mm}$, body, $12.0 \mathrm{~mm}$, base, $11.0 \mathrm{~mm}$.

Surface treatment: Interior surface smooth, exterior surface blistered from intense heat.

Height: $18.0 \mathrm{~cm}$

Rim: Parallel and opposing incised lines.

Body: tool punctates in uneven rows.

Vessel 2, Feature 1

Form: Large plain jar with a portion of the rim, body, and base.

Temper: Bone and grog.

Rim and lip profile: Direct rim with a flat lip.

Firing: Fired in a reduced atmosphere.

Interior surface color: very dark gray (10YR3/1).

Exterior surface color: brown (7.5YR4/2).

Surface treatment: Both exterior and interior surfaces have been smoothed.

Thickness: rim, $8.0 \mathrm{~mm}$, body, $11.8 \mathrm{~mm}$, base, $13.9 \mathrm{~mm}$; the base is $13.0 \mathrm{~cm}$ in diameter.
Vessel 3 (Figure 10), Feature 1

Form: Portion of a large jar. Vessel height is $20.0 \mathrm{~cm}$ Decoration: Parallel and opposed diagonal incised lines around the rim, alternating in direction with intervening triangular spaces filled with tool punctates. There are horizontal incised lines at the top and bottom of the rim panel. Canton Incised.

Temper: Grog.

Rim-lip profile: Direct rim with flat lip.

Firing: undetermined

Color: The exterior and interior surfaces are a dark brown to a dark reddish-brown.

Surface treatment: Both surfaces have been smoothed.

Thickness: rim, $6.3 \mathrm{~mm}$, body, $8.0 \mathrm{~mm}$, base, $14.0 \mathrm{~mm}$.

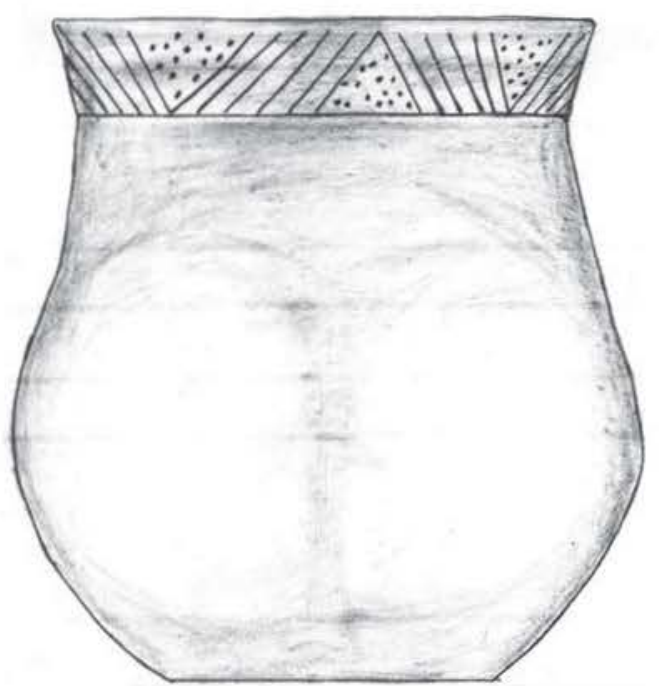

Figure 10. Canton Incised jar from Feature 1.

Vessel 4 (Figure 11), Feature 1

Form: Represented by twenty-eight large sherds from a large jar.

Decoration: Long $(2.2-3.9 \mathrm{~cm})$ randomly spaced slash punctates across the vessel body that are up to $4.4 \mathrm{~mm}$ wide.

Temper: Bone/grog; crumbly texture.

Rim and lip profile: Rim and lip are absent.

Firing: Fired in a reduced atmosphere and cooled in the open air.

Color: Interior color is a dark reddish-brown (5YR3/3). The exterior color is a very dark gray (7.5YR3/1)

Thickness: Body, $9.8 \mathrm{~mm}$

Surface treatment: Interior and exterior surfaces are smoothed. 
Vessel 5 (Figure 12), Feature 1

Form: Bottle with much of the bottle neck, the rim, and lip missing. Height, $18.0 \mathrm{~cm}$, neck height, $14.0 \mathrm{~cm}$; the neck is slightly tapered. Base diameter, $8.5 \mathrm{~cm}$

Decoration: Five horizontal engraved lines, poorly executed, at the junction of the neck and the body. Below the bottom horizontal engraved line are a series of pendant excised triangles surrounded by engraved outlines. The engraved decoration appears to be a variant of Hickory Fine Engraved (Suhm and Jelks 1962:71-72).

Temper: Grog.

Color: Exterior color is a grayish-brown with fireclouding; interior color is a light grayish-brown.

Firing: undetermined.

Thickness: Neck, $5.5 \mathrm{~mm}$, body, $6.7 \mathrm{~mm}$, base, $10.0 \mathrm{~mm}$
Surface treatment: Exterior surface is burnished.

Vessel 6: Jar from Feature 4 (see Figure 5)

Form: Jar; Height: $20.5 \mathrm{~cm}$. Orifice diameter: 19.2 $\mathrm{cm}$. Base diameter: $10.0 \mathrm{~cm}$.

Decoration: The rim is decorated with diagonal opposed incised lines, creating a series of incised triangles. The body is covered with four repeating panels of diagonal incised lines separated by vertical incised lines. Dunkin Incised (Suhm and Jelks 1962:37-38).

Temper: Grog.

Rim and lip profile: Direct rim with a flat lip.

Color: Interior color ranges from a dark brown to a light brown with fire clouding. Exterior color is a light reddish-brown to dark brown with fire clouding.

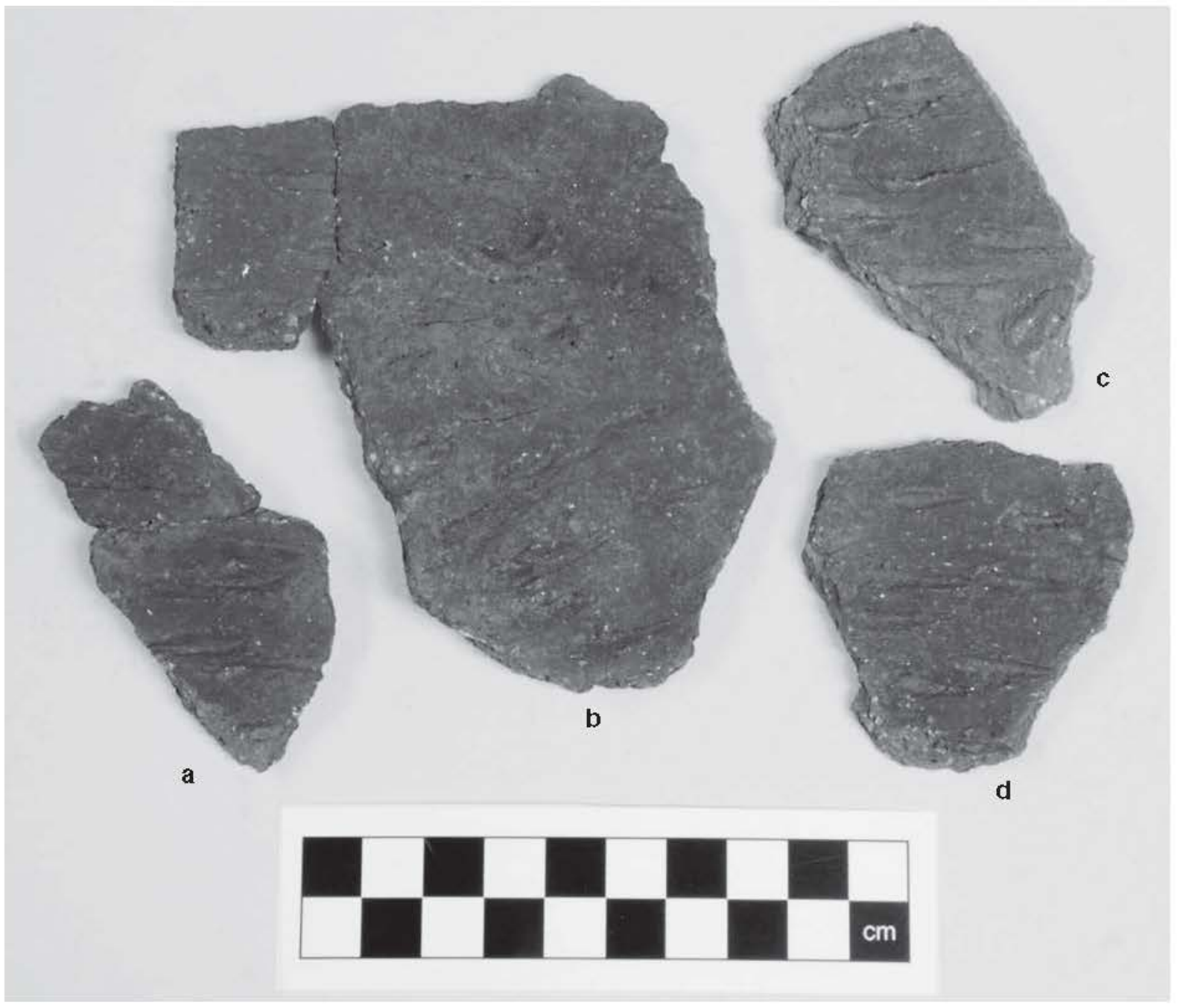

Figure 11. Large jar with slash punctates from Feature 1. 


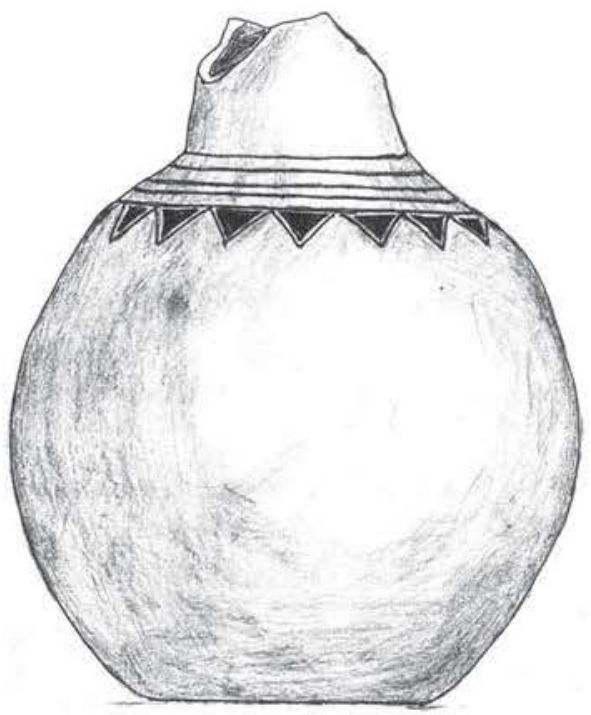

Figure 12. Engraved bottle from Feature 1 at the Henry Chapman site.

Firing: undetermined.

Thickness: rim, $5.0 \mathrm{~mm}$, body, $5.0 \mathrm{~mm}$, base, 8.0 $\mathrm{mm}$.

Surface treatment: Interior and exterior surfaces have been smoothed.

Vesse1 7: Plain jar from N105-110 E 25-30, Depth $0-1 \mathrm{ft}$. bs. The partial vessel was from a general level context with no mention of any pit feature. Form: Large jar; Orifice diameter: $40.0 \mathrm{~cm}$ Decoration: plain

Temper: Grog/hematite; crumbly texture

Rim and lip profile: Direct rim with a flat lip.

Color: Exterior and interior coloring is a very dark gray (7.5YR3/1).

Firing: Reducing

Thickness: rim, $8.9 \mathrm{~mm}$, body, $10.8 \mathrm{~mm}$.

Surface treatment: Interior/exterior surfaces have been smoothed.

\section{Instrumental Neutron Activation Analysis of Caddo Pottery from the Henry Chapman site}

Two decorated sherds, one a Holly Fine Engraved sherd, from the Henry Chapman site were analyzed by instrumental neutron activation analysis (INAA) at the University of Missouri Reactor Center. The results show that both sherds are from vessels made from local clay sources, as they were assigned to the Titus chemical reference group (Descantes et al. 2003; Perttula 2002). These findings should be considered preliminary until reanalysis of the entire Caddo INAA database, currently underway, is completed.

\section{Mud dauber nests}

Two mud dauber nests were recovered in the excavations at the Henry Chapman site. They are from two different parts of the site, suggesting there are burned structures in both locations.

Lot 35, N70-90 E0-5, depth, $1.33 \mathrm{ft}$. bs. This is a yellowish-brown fired mud dauber nest from a possible burned house. There are grass and cane impressions on one side. Length, $5.5 \mathrm{~cm}$, width, 4.0 $\mathrm{cm}$, and thickness, $3 \mathrm{~cm}$.

Lot 1, N140 E45-50, depth 1.5-2.0 ft. bs. Dark brown fired mud dauber nest. Length, $2.4 \mathrm{~cm}$, width, $1.2 \mathrm{~cm}$, thickness, $1.1 \mathrm{~cm}$.

\section{Daub}

Only three pieces of daub are in the collections from the Henry Chapman site. Perhaps the structures at the site did not have a wattle and daub covering.

Lot 220, N95-100 E40-45, depth 0-1 ft. Fired clay, smooth one side, while the opposite side has grass/cane impressions; very hard. It is reddish-yellow (7.5YR7/6) in color. Length, $38.3 \mathrm{~mm}$, width, $32.8 \mathrm{~mm}$, thickness, $19.1 \mathrm{~mm}$.

Lot 1146, N135-140 E15-20, depth 1.0-1.5 ft bs. Very hard and light brown fired clay piece with small cane/stick impressions on one side. It was found in the soil zone above Feature 3, the cremation.

Lot 6, N145-150 E45-50, depth 1.0-1.5 ft. bs. One piece of daub with a sandy paste and hematite inclusions; it is soft and gritty. There are grass impressions on one side, while the other side is not smoothed.

\section{Lithic Artifacts}

There were not many lithic artifacts recovered from the excavations at the Chapman site. This could be due to the lack of screening of the archaeological deposits and/or the size of the mesh on the screen used in the excavations. It is possible, however, that the Chapman site may be similar to other Caddo sites in the area that do not have an abundance of lithic materials (Walters 2008). This paucity of lithic artifacts may be a product of an increasing reliance on agriculture by the Caddo at the time of 
the site occupation, and thus less hunting activities requiring stone tools, or simply changing technologies (i.e., increased use of bone and wood tools). Furthermore, not all of the lithic artifacts recovered from the Chapman site can be associated with any certainty with the Caddo occupation. Certainly the dart points, such as the Kent point, are associated with Late Archaic and Woodland period occupations in East Texas. Most favorable landforms in East Texas usually have evidence of repeated occupations through time.

\section{Chipped Stone tools}

There are 14 chipped stone tools in the Henry Chapman site lithic assemblage. They include bifaces $(n=1)$, a bifacial scraper $(n=1)$, dart point $(n=3)$, arrow point $(\mathrm{n}=1)$, flake tools $(\mathrm{n}=5)$, perforator $(\mathrm{n}=1)$, and a blade tool $(n=1)$. Lithic raw materials used in the manufacture of the tools include quartzite $(n=4)$, petrified wood $(n=1)$, brown chert $(n=1)$, gray chert $(n=2)$, light gray chert $(n=2)$, light grayish-brown chert $(n=1)$, dark gray chert $(n=1)$, black chert $(n=1)$, and a yellowish-brown chert $(\mathrm{n}=1)$.

1. Lot 518, N80-85 W15-20, 0.5-1 ft. bs. Biface, with retouching flakes around the edge of the tool. Red quartzite. Length, $52.5 \mathrm{~mm}$, width, $22.8 \mathrm{~mm}$, thickness, $7.2 \mathrm{~mm}$.

2. Lot 586, N135-140 E30-35, 1.5-2 ft. bs. Bifacial scraper, with a slanting bit-like face on one side. Gray quartzite. Length, $43.7 \mathrm{~mm}$, width, $35.1 \mathrm{~mm}$, thickness, $10.2 \mathrm{~mm}$.

3. Lot 447, N75-80 E5-10,1.5-2 ft. bs. Dart point base, square with an impact fracture. Gray quartzite. Length, $18.6 \mathrm{~mm}$, width, $26.9 \mathrm{~mm}$, thickness, $7.8 \mathrm{~mm}$.

4. Lot 1112, N80 E19, $2.5 \mathrm{ft}$. bs (in gopher pocket). Dart point, with weak shoulders and a convex base. Kent type. Light grayish-brown chert. Length, $42.2 \mathrm{~mm}$, width, $14.5 \mathrm{~mm}$, thickness, $7.6 \mathrm{~mm}$.

5. Lot 76, N45-50 E0-5, depth 0-1 ft. bs. Dart point with an impact fracture one face. Petrified wood. Length, $20.1 \mathrm{~mm}$, width, $31.7 \mathrm{~mm}$, thickness, $6.0 \mathrm{~mm}$.

6. Lot $82, \mathrm{~N} 45-50$ E0.5, depth 0-1 ft. bs. Unifacial arrow point on a flake with edge retouch flake scars; the base is missing. Light brown (7.5YR6/3) chert with white inclusions. Length, $18.8 \mathrm{~mm}$, width, $14.0 \mathrm{~mm}$, thickness, $2.5 \mathrm{~mm}$.

7. Lot 202, N110-115 E35-40, depth 0-1 ft. bs. Uniface flake tool. Gray (10YR5/1) chert, with a small spot of cortex on one edge. Length, 25.7 $\mathrm{mm}$, width, $23.4 \mathrm{~mm}$, thickness, $5.2 \mathrm{~mm}$.

8. Lot 403, N110-115 E10-15, depth 0-0.5 ft. bs. Bifacial flake tool with a snap fracture on one edge. Glossy dark gray chert (heat treated).

9. Lot 553, N130-135 E30-35, depth 1.0-1.5 ft. bs. Perforator that is flaked on both sides of the tool. Glossy black chert (heat treated). Length, $36.7 \mathrm{~mm}$, width, $17.3 \mathrm{~mm}$, thickness, $4.9 \mathrm{~mm}$.

10. Lot 2, N140-145 E45-50, depth 1.0-1.5 ft. bs. Unifacial flake tool from a primary flake. There are retouch pressure flakes on one side of the tool. The cortex color is a strong brown (7.5YR4/6), and the interior color is a yellowish-brown (10YR5/6). Length, 37.7 $\mathrm{mm}$, width, $20.3 \mathrm{~mm}$, thickness, $7.6 \mathrm{~mm}$.

11. Lot 629, N125-130 E30-35, backfill. Flake tool from a secondary chert flake. Pressure flake scars on one edge, and a snap fracture on one edge. Cortex is a brown $(7.5 \mathrm{YR} 5 / 3)$ color, but the interior color is gray (7.5YR6/1). Length, 51.5 $\mathrm{mm}$, width, $26.8 \mathrm{~mm}$, and thickness, $9.8 \mathrm{~mm}$.

12. Lot 6, N145-150 E45-50, depth 1.0-1.5 ft. bs. Flake tool from a secondary chert flake, and pressure flaking on one end. Brown cortex, light gray interior. Length, $32.9 \mathrm{~mm}$, width, $19.5 \mathrm{~mm}$, thickness, $7.5 \mathrm{~mm}$.

13. Lot 12, N135-140 E45-50, depth 1.0-1.5 ft. bs. A utilized blade from a secondary chert flake, with a snap fracture on one end. It has a brown cortex with a light gray interior. Length, 35.4 $\mathrm{mm}$, width, $13.2 \mathrm{~mm}$, thickness, $3.6 \mathrm{~mm}$.

14. Lot 1139, N50-55 E10-13, depth-1.0-1.5 ft. bs. A bifacial flake tool made from a secondary red (2.5YR5/8) quartzite flake.

\section{Chipping debris}

There are 19 pieces of chipping debris in the collection: 10 with cortex and nine interior or 
non-cortical flakes. Eight of the flakes fall in the 2.54 $\mathrm{cm}$ size class, 10 fall in the $1.27 \mathrm{~cm}$ size class, and one belongs to the $0.64 \mathrm{~cm}$ size class.

Twelve of the flakes are chert (five gray, two grayish-brown, two light brown, one dark gray, one red, one gray/red inclusions), and there is one white novaculite flake. Three others are quartzite flakes (two gray and one red), and there are also two hematite flakes, and a milky quartz flake.

\section{Cores/tested cobbles}

The cores include exhausted cores and tested cobbles of chert $(n=3)$ and quartzite $(n=2)$.

1. Lot 1, N70-90, W0-5, 0-1 ft. bs. Red chert exhausted core with multiple flake scars. No cortex is present. Length, $28.5 \mathrm{~mm}$, width, 23.3 $\mathrm{mm}$, thickness, $15.0 \mathrm{~mm}$.

2. Lot $775, \mathrm{~N} 130-140 \mathrm{E} 35-40,1.5-2 \mathrm{ft}$. bs. Gray chert exhausted core. Multiple flake scars and no cortex remaining. Length, $34.1 \mathrm{~mm}$, width, $25.0 \mathrm{~mm}$, thickness, $18.5 \mathrm{~mm}$.

3. Lot 3, N70-90, W0-5, 0-1 ft. bs. Gray quartzite core with cortex remnants. Flake scars are present on both sides of the core. Length, 37.1 $\mathrm{mm}$, width, $25.0 \mathrm{~mm}$, thickness, $18.0 \mathrm{~mm}$.

4. Lot 12, N70-90, W0-5, 0-1 ft. bs. Chert cobble core with two flake scars. Cortex is a yellowish-red (5YR5/6), and the interior color is a reddish-gray (5YR5/2). Length, $22.7 \mathrm{~mm}$, width, $22.0 \mathrm{~mm}$, thickness, $14.4 \mathrm{~mm}$.

5. Lot 2, N70-90, W0-5, 0-1 ft. bs. Round quartzite tested cobble with one flake scar. Very pale brown (10YR7/4). Length, $70.0 \mathrm{~mm}$, width, $60.0 \mathrm{~mm}$, thickness, $39.0 \mathrm{~mm}$.

\section{Ground Stone tools}

The ground stone tools at the Henry Chapman site include five celts and three abraders.

1. Celt. Lot 39, N77 W4, 0.67 ft. bs. Graywacke sandstone, dark olive gray (5Y3/2). Length, $88.8 \mathrm{~mm}$, width, $49.2 \mathrm{~mm}$, thickness, $41.3 \mathrm{~mm}$. The celt was complete, and the bit section is polished. The amount of polishing decreased away from the bit to the battered poll end (Figure 13b).
2. Celt. Lot 913, N130-140 E25-30, depth 0.5-1.0 ft. bs. Reddish-black (2.5YR2.5/1) hematite. This is a complete tool showing chip marks on the bit and smoothing striation marks running parallel to the bit on the bit end and lengthwise on the body. The celt showed flake scars on the body from its manufacture. Length, $79.9 \mathrm{~mm}$, width, $50.3 \mathrm{~mm}$, thickness, $29.1 \mathrm{~mm}$ (Figure 13c).

3. Celt fragment. Lot $32, \mathrm{~N} 70-90 \mathrm{E} 0-5$, no depth given. Polished fragment with a portion of the bit. This celt was found in association with Celt \# 1 and a fired mud dauber nest in a possible burned house. Very dark gray (5Y3/1) sandstone. Length of the fragment, $39.4 \mathrm{~mm}$, width, $47.2 \mathrm{~mm}$, thickness, $8.0 \mathrm{~mm}$.

4. Celt fragment. Lot 485, N65-70 E5-10, 0-0.5 $\mathrm{ft}$. The celt fragment has part of the polished bit end, but not the actual bit, and the remainder of the fragment has been smoothed. Dark olive gray $(5 \mathrm{Y} 3 / 2)$ sandstone. Length of the fragment, $61.0 \mathrm{~mm}$, width, $49.7 \mathrm{~mm}$, thickness, $10.3 \mathrm{~mm}$ (Figure 13a).

5. Celt fragment. Lot 587, N135-140 E30-35, 1.5-2.0 ft. bs. Polished section of a celt with a portion of the bit. Polished striations run length-wise down the body of the celt. Olive gray (5Y4/2) sandstone. Length of the celt fragment, $33.6 \mathrm{~mm}$, width, $20.6 \mathrm{~mm}$, thickness, $6.7 \mathrm{~mm}$.

6. Sandstone abrader. Lot 237, N100-105 E25$30,0-1 \mathrm{ft}$. bs. The abrader is made from a soft red $(2.5 \mathrm{YR} 4 / 6)$ ferruginous sandstone. There are two parallel grooves, $7.1 \mathrm{~mm}$ wide, on one surface. The opposite side has a concave smoothed surface.

7. Sandstone abrader/pigment rock. Lot 517, N80-85 E15-20, 0.5-1 ft. bs. The abrader/ pigment rock is made from a fine-grained soft red (10R4/6) sandstone. One side has shallow parallel grooves, while the opposite side has two parallel grooves that are $3.0 \mathrm{~mm}$ wide that resulted from its use as an abrader. Around the edges of the tool are fine cut marks where materials were collected for pigments.

8. Sandstone abrader. Lot 33-34, N70-90 W05, $0.83 \mathrm{ft}$. bs. Catahoula sandstone outcrops in portions of East Texas and Northwest 
Louisiana and occurs in Tertiary age rocks as a whitish tuffaceous sandstone. This abrader from the Chapman site is made from a coarse, white (10YR8/1), Catahoula sandstone and it is broken in two pieces. One side has multiple grooves that are up to $15.0 \mathrm{~mm}$ wide and 7.0 $\mathrm{mm}$ deep. One groove is V-shaped, $10.4 \mathrm{~mm}$ wide, and $5.0 \mathrm{~mm}$ deep. The opposite side has two shallow parallel grooves. This abrader was found in association with Celt $\# 1$ and $\# 3$ and a mud dauber nest in a possible burned house.

\section{Animal bone}

Mr. Whiteside's journal lists the following entries for animal bone:

- Lot 516 N75-80 E0-5, 0-0.5 ft. bs. Charred animal bone from Feature 2. Collected March 28, 1958 and delivered to Archeological Museum, U.T., August 21, 1958. (TARL records indicate they were discarded on August 21, 1969 , without analysis).

- Lot 815 N130-140 E35-40, 2.5-3.0 ft. bs. No description.

- Lot $820 \quad \mathrm{~N} 140-150$ E35-40, 0-0.5 ft. bs. No description.

- Lot 5 N145-150 E45-50, 0.5-1.0 ft. bs. No description.

- Lot $6 \quad$ N145-15- E45-50 1.0-1.5 ft. bs. No description.

- Lot $820 \quad \mathrm{~N} 140-150$ E35-40 0-0.5 ft. bs. Unburned large mammal $(8.6 \times 1.8 \times 6.1 \mathrm{~cm})$

Animal bone without lot numbers included in the Chapman collection include: 10 fractured large mammal long bones, three of which were burned; one fractured long bone from a large bird; one unburned deer vertebra; nine deer teeth; and five fractured small mammal bone, two that had been burned.

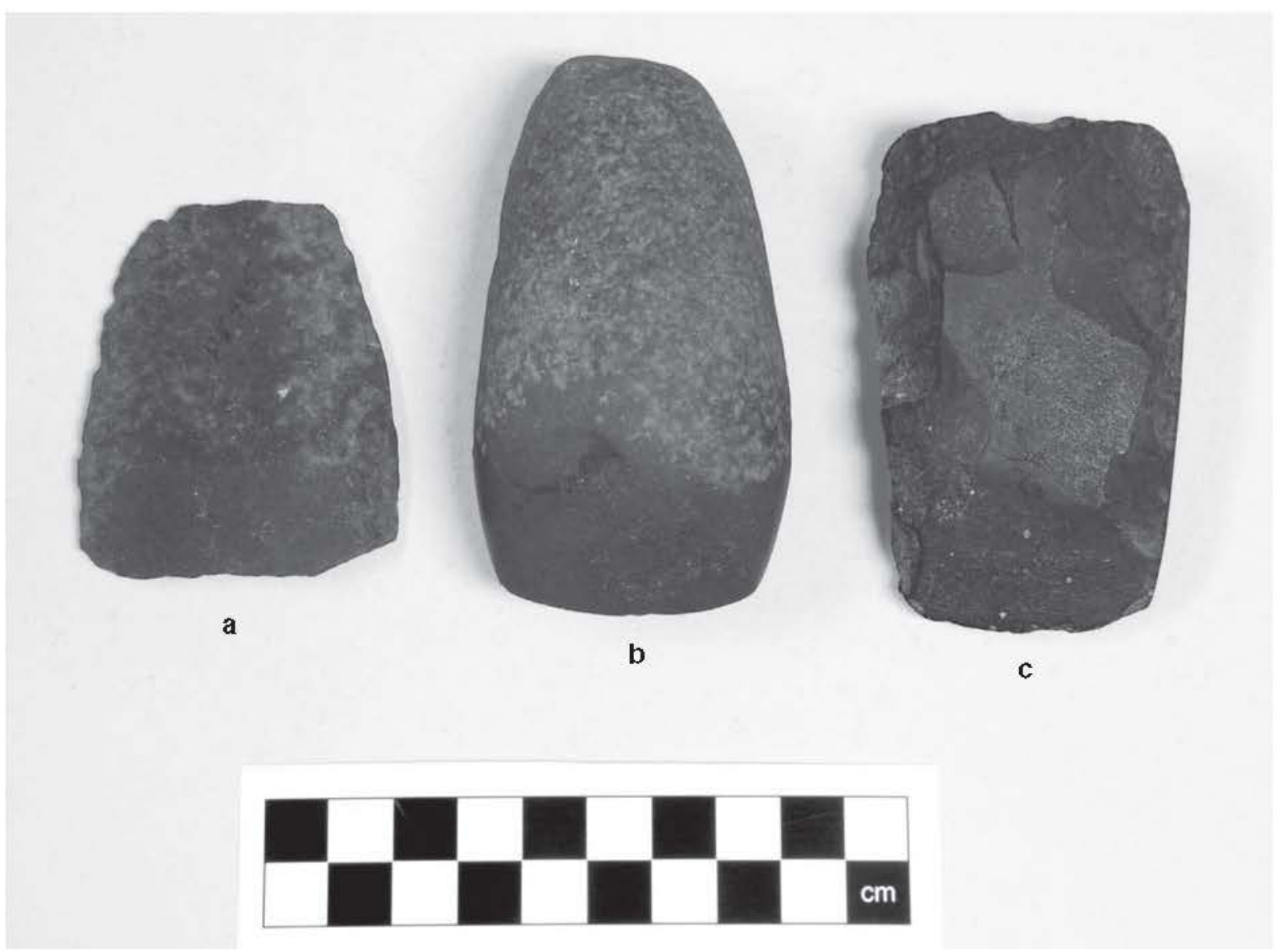

Figure 13. Celts from the Chapman site: a, sandstone celt; b, graywacke sandstone celt; $c$, hematite celt. 


\section{Possible human bone and Reported human bone}

There are nine unburned and possible human cranium fragments in the collection, measuring up to $4.3 \mathrm{~mm}$ in thickness. None of these have provenience information. Two lot numbers have human remains: Lot 1147 (Bone Burial 2, Feature 5) and Lot 1148 (cremation bone, Feature 3).

\section{COMPARISONS TO EARLY CADDO MOUND CENTERS AND HABITATION SITES IN EAST TEXAS}

As time is paramount to the science of archaeology, placing the Chapman site in some chronological order is essential to understanding the archaeological record of the site and the Caddo settlement of this area. Certain ceramic styles associated with the Alto phase are present at the Henry Chapman site. It would be tempting to use that association to identify the Chapman site as a component of the early Caddo [Alto phase] as defined at the George C. Davis site. However, Story reiterates "components of this phase [Alto] are no where common even though some of the diagnostics, such as Weches Fingernail Punctated and Holly fine Engraved, have wide distributions" (Story 2000:20). Again, based on the artifacts recovered from Mr. Whiteside's excavations at the Chapman site, the main occupation at the site would seem to occur during the Early Caddo period (ca. A.D. 1000-1200), but during what part of the Early Caddo era can only be answered by more absolute dates. At the Chapman site, there is no evidence of the stylistic diversity that characterizes the fine ware ceramics characteristic of the Middle Caddo period (ca. A.D. 1200-1400), nor are there increasing percentages of brushing on utility wares. However, alternatively, groups in the Prairie Creek area may have held on to local ceramics traditions while other contemporaneous Caddo groups changed their ceramic styles, or else chose not to decorate their utility wares with brushing.

There are a few sites, either mound centers or habitation locales, known in Early Caddo times that provide some relevant comparisons with the archaeological record from the Henry Chapman site. I begin with mound centers.

\section{Early Caddo mound centers}

There are three known Early Caddo mound centers in the general area of the Henry Chapman site. It is not know if the Chapman site was contemporaneous with any of these ceremonial centers but the Chapman site does have ceramics that are similar to some of those found at these locations.

The Boxed Springs site (41UR30) is some 28 $\mathrm{km}$ to the north of the Chapman site on the Sabine River. This is an Early Caddo (ca. A.D. 900-1200) multiple mound center that was recorded and partially investigated by Sam Whiteside in the early 1960 s (Perttula et al. 2000). Artifacts from excavations and from a cemetery looted in the 1980s include Holly Fine Engraved and Hickory Fine Engraved, Spiro Engraved, Coles Creek Incised, Weches Fingernail Impressed, Kiam Incised, East Incised, Crenshaw Fluted, and Crockett Curvilinear Incised vessels.

Engraved wares at the Hudnall-Pirtle site (41RK4), an early Caddo mound center on the Sabine River some $48 \mathrm{~km}$ to the east of the Chapman site, included examples of both Holly and Hickory Fine Engraved but it was noted that not all of the engraved decorations represented "fine engraved" lines but rather the lines were described as being thicker and generally coarser (Bruseth and Perttula 2006:90-91); this was not the case with the Hickory and Holly Fine Engraved sherds from the Henry Chapman site. Other Early Caddo pottery types noted at the Hudnall-Pirtle site were Davis Incised, Dunkin Incised, Weches Fingernail Impressed, Pennington Punctated-Incised, and Crockett Curvilinear Incised. There were also sherds similar to Coles Creek Incised, var. Coles Creek and var. Hardy. There were six pipe fragments from long-stemmed Red River pipes recovered from excavations at the site. A total of 93 projectile points were recovered at the Hudnall-Pirtle site. The main arrow points include: Alba (42\%), Catahoula (12.5\%), Steiner (10.4\%), and Colbert (10.4\%) (Bruseth and Perttula 2006).

The George C. Davis site (41CE19), some 85 $\mathrm{km}$ to the south of the Chapman site, is one of the better dated/investigated Early Caddo mound centers in East Texas. Dates at the Davis site indicate the Alto phase occupation here dated from the late A.D. 800 s to A.D. 1300 . Dee Ann Story (2000), in the introduction to the classic The George C. Davis Site, Cherokee County, Texas report, defines the Alto phase based on the following co-occurring ceramic types: Holly Fine Engraved, Weches Fingernail Punctated, Davis Incised, Crockett Curvilinear Incised, Pennington Punctated Incised, Dunkin Incised, and Duren Neck Banded. Less diagnostic, but commonly present on Alto phase sites, are Hickory Fine Engraved ceramics, pinched ridge pottery, 
long-stemmed Red River pipes, Alba arrow points, Gahagan bifaces, petaloid celts, and expedient tools made on flakes. Story (2000) contends that this phase, found in both mound centers and small habitation sites across a large area, represents the first distinctively Caddo remains in the middle Sabine and Neches river basins.

\section{Local Caddo habitation sites}

Compared to later Caddo sites, habitation sites with Early Caddo ceramics, such as are found at the Henry Chapman site, are scarce in this area of East Texas. Story (2000) suggests that the local region was not heavily populated at this time.

The Wolf site (41SM195), a small Caddo habitation site located on a nearby drainage to the Chapman site, has radiocarbon and OCR dates indicating a mid-fourteenth century occupation (Walters 2003). Significantly, however, the ceramic assemblage from this site lacks brushed pottery, as does the Henry Chapman site ceramic assemblage. Decorative techniques in the ceramics from the Wolf site include: punctated (52.4\%), engraved $(29.5 \%)$, incised $(14.3 \%)$, and punctated-incised $(3.8 \%)$. There is one engraved sherd similar to Holly Fine Engraved with excised areas, nested excised triangles, and red pigment in the lines. There were no ceramic pipes recovered from the Wolf site.

The Broadway site (41SM273), located some $24 \mathrm{~km}$ to the west of the Chapman site, has evidence of an early Caddo occupation dating ca. A.D. $900-1000$ based on radiocarbon dates and the presence of small amounts of sherds from Holly Fine Engraved, Weches Fingernail Punctated, Dunkin Incised, as well as Crockett Curvilinear Incised, and long-stemmed Red River pipe sherds (Perttula and Nelson 2004). Perttula and Nelson (2004) surmised that the early Caddo occupation at the Broadway site was contemporaneous with, and that perhaps there was some level of contact/interaction between, the Caddo groups that occupied the George C. Davis site, but that the Caddo living at the Broadway site were part of a different social group.

Also located in Smith County is the Joe Meyers site (41SM73) in the Neches River basin, where members of the East Texas Archeological Society recovered Alto phase ceramics from habitation areas and burials (Johnson 1961). The Meyers site was the only one of 34 ceramic site in the Lake Palestine project area that contained early Caddo ceramic types (Jelks 1958).
The burials at the site included six single burials and one multiple burial that contained the remains of probably four individuals. Fifteen vessels were associated with the burials, including Bowles Creek Plain, Hickory Fine Engraved, Weches Fingernail Impressed, and Canton Incised (Jelks 1958). Surface collections from the site had sherds from the following early Caddo ceramic types: Hickory Fine Engraved, Davis Incised, Dunkin Incised, Canton Incised, and Weches Fingernail Impressed.

The six Weches Fingernail Impressed sherds were all rims with flat lips. A description of the ceramic type Weches Fingernail Impressed describes the lips as being rounded and flat in about equal numbers (Suhm and Krieger 1954:364). Thirteen plain rims from the Myers site were also described as being flat. At the Henry Chapman site 34 (34\%) of the 100 rim sherds had flattened lips.

Interestingly, Jelks (1958) noted that stone material was not common at the Meyers site, a situation similar to the material culture at the Henry Chapman site.

To the east in adjoining Gregg County are two habitation sites that have Alto phase artifacts (Jones 1957). Grace Creek \#1 (41GG33) was a probable Caddo habitation site with Alto phase ceramics $(n=593)$ and arrow points $(n=83)$, of which 76 were of the Alba type. From Grace Creek \#1, Jones recovered sherds of Davis Incised ( $n=49$ ), Dunkin Incised $(n=19)$, Crockett Curvilinear Incised $(n=4)$, Hickory Fine Engraved $(n=2)$, Holly Fine Engraved $(n=1)$, Pennington Punctated-Incised $(n=1)$, and Weches Fingernail Impressed $(n=4)$. Jones (1957:Figure 51g-h) listed two sherds as examples of Dunkin Incised, but they are clearly a Lower Mississippi Valley type seen in pre-A.D. 1050 contexts in the Caddo area: Coles Creek Incised, var. Coles Creek.

Grace Creek \#2 (41GG34) had a small amount of early Caddo material, including sherds, one Red River pipe stem, and one Alba arrow point. Early Caddo ceramic types collected were Weches Fingernail Impressed $(n=2)$, Dunkin Incised $(n=1)$, Davis Incised $(n=1)$, and a Hickory Fine Engraved rim with a flat lip $(\mathrm{n}=1)$.

\section{CONCLUSIONS}

The Henry Chapman site was a prehistoric Caddo habitation site much like other Caddo sites in the northern part of Smith County, and in the Sabine River basin. These sites were probably 
occupied by kinship-related groups who cooperated in the gathering, production, and consumption of local resources. No evidence was obtained by Mr. Whiteside's investigations confirming the cultivation of domesticated crops such as maize but investigations at other nearby sites suggest that agricultural activities supplemented the hunting and gathering of native plants in the Caddo diet. Evidence of large utility vessels at the site is indicative of the change by Caddo peoples after ca. A.D. 850 from hunting-gathering to a more sedentary lifestyle with the storage of foodstuffs, including domesticated plants. Large carinated bowls present at the Chapman site would seem to indicate that feasting by Caddo living there also played a role in their social life.

Excavations at the Chapman site seem to indicate the presence of three or more permanently constructed houses, either all occupied at one time or more likely it is the case that they represent a sequence of houses. There is evidence that one or more of the houses may have burned, either by accident or intentionally. These houses, following the settlement pattern of other small farmsteads, probably were not occupied for more than one decade at a time, and thus if the houses represent sequential use, the Henry Chapman site may have been occupied overall for ca. 30 years.

There were two burials reported from the Chapman site, although only one of these was documented in any detail. This burial, Feature 3, was a partial cremation and contained no obvious grave goods. A single radiocarbon date from the burial indicates the burial took place somewhere between $\mathrm{AD}$ 1280-1440. Cremations of this type are atypical in Caddo mortuary traditions, although an early Caddo cremation has been reported from the Boxed Springs (41UR30) mound center on Big Sandy Creek near its confluence with the Sabine River. Artifacts in the grave fill in Feature 3 at the Henry Chapman site indicate that the burial took place during (or after) the principal Caddo occupation of the site. A date obtained from the burial appears to be anomalously too recent based on the ceramics recovered from excavations at the Chapman site.

In summary, the Henry Chapman site represents a local group of folks that lived in this part of East Texas between ca. A.D. 1000-1200 that are culturally different from other Caddo groups, although it appears to be linked to them in some fashion by direct contact or interaction. The Henry Chapman site may have been occupied by a certain local Caddo group that held on to certain traditions (such as distinctive styles of decorations on ceramic vessels) longer than did contemporaneous groups, or they resisted changes in utility ware decorative styles (such as brushing on vessels), longer than groups in other areas. It is uncertain what the nature of the social and cultural glue was that held these scattered Caddo groups in this area together. Hopefully, studies of other Caddo sites investigated by Mr. Whiteside and others on Prairie Creek and surrounding drainages will shed more light on how the Henry Chapman site fits into Caddo cultural history.

\section{REFERENCES CITED}

Bruseth, James E. andTimothy K. Perttula, with contributions by Gayle J. Fritz and Bonnie C. Yates

2006 Archeological Investigations at the Hudnall-Pirtle Site (41RK4): An Early Caddo Mound Center in Northeast Texas. Caddo Archeology Journal 15:57158.

Descantes, Christophe, Robert J. Speakman, and Michael D. Glascock

2003 Letter Report to Timothy K. Perttula with enclosed figures and tables, September 3, 2003. University of Missouri Research Reactor, Columbia.

Jelks, Edward B.

1958 Appraisal of the Archeological Resources of Blackburn Crossing Reservoir, Anderson, Cherokee, Henderson, and Smith Counties, Texas. A Project of the Inter-Agency Archeological Salvage Program. National Park Service. U.S. Department of the Interior.

Johnson, Leroy

1961 An Archeological Survey of Blackburn Crossing Reservoir on the Upper Neches River. Bulletin of the Texas Archeological Society 31:213-238.

Jones, Buddy C.

1957 The Grace Creek Sites, Gregg County, Texas. Bulletin of the Texas Archeological Society 28:198-231.

Perttula, Timothy K.

2002 Archeological Evidence for the Long-Distance Exchange of Caddo Indian Ceramics in the Southern Plains, Midwest, and Southeastern United States. In Geochemical Evidence for Long-Distance Exchange, edited by Michael D. Glascock, pp. 89-107. Bergin and Garvey, Westport, Connecticut.

Perttula, Timothy K. and Bo Nelson

2004 Woodland and Caddo Archeology at the Broadway or Kanduts'ah Kuhnihdahahdisa' Site (41SM273) 
on the City of Tyler-Lake Palestine WTP Project, Smith County, Texas. Report of Investigation No. 50. Archeological \& Environmental Consultants, LLC, Austin.

Perttula, Timothy K., Diane Wilson, and Mark Walters

2000 An Early Caddoan Period Cremation from the Boxed Springs Mound Site (41UR30) in Upshur County, Texas, and a report on Previous Archaeological Investigations. Journal of Northeast Texas Archaeology 12:31-71.

Phillips, Philip

1970 Archaeological Survey in the Lower Yazoo Basin, Mississippi, 1949-1955. Papers of the Peabody Museum of American Archaeology and Ethnology 60. Harvard University, Cambridge.

Story, Dee Ann

2000 Introduction. In The George C. Davis Site, Cherokee County, Texas, by H. Perry Newell and Alex D. Krieger, pp. 1-31. $2^{\text {nd }}$ Edition. Society for American Archaeology, Washington, D.C.

Suhm, Dee Ann and Edward B. Jelks (editors)

1962 Handbook of Texas Archaeology: Type Descriptions. Special Publication No. 1, Texas Archaeological Society, and Bulletin No. 4, Texas Memorial Museum, Austin.
Suhm, Dee Ann and Alex D. Krieger, with contributions from Edward B. Jelks

1954 An Introductory Handbook of Texas Archeology. Bulletin of the Texas Archeological Society 25:1562.

Walters, Mark

2005 A Profile in East Texas Archeology. Bulletin of the Texas Archeological Society 75:119-120.

Walters, Mark, with contributions from Leslie G. Cecil, Linda Scott Cummings, J. Phil Dering, Jeffrey R. Ferguson, Michael D. Glascock, Timothy K. Perttula, LeeAnna Schniebs, Harry J. Shafer, Jesse Todd, and Chester P. Walker

2008 Life on Jackson Creek, Smith County, Texas: Archeological Investigations of a $14^{\text {th }}$ Century Caddo Domicile at the Leaning Rock Site (41SM325). Caddo Archeology Journal 17:1-114.

Walters, Mark, with contributions by Phil Dering

2003 The Wolf Site (41SM195), Smith County, Texas. Journal of Northeast Texas Archaeology 18:1-21.

Walters, Mark and Patti Haskins, with contributions by David H. Jurney, S. Eileen Goldborer, and Timothy K. Perttula

1998 Archaeological Investigations at the Redwine Site (41SM193), Smith County, Texas. Journal of Northeast Texas Archaeology 11:1-38. 